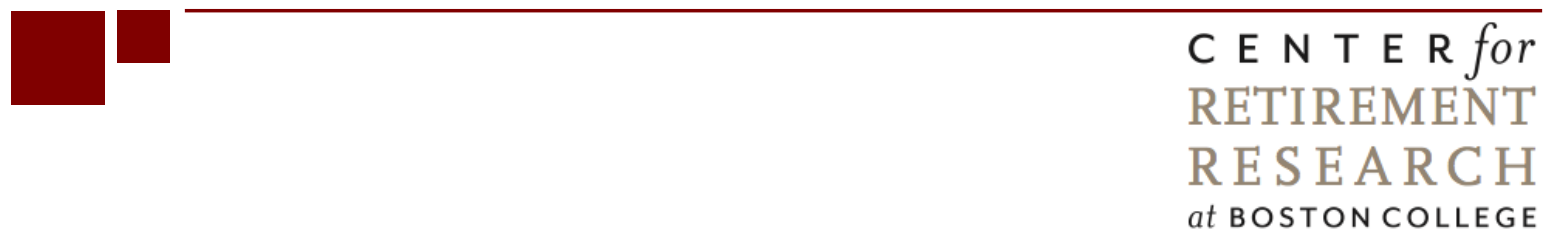

\title{
THE IMPACT OF POPULATION AGING AND DELAYED RETIREMENT ON WORKFORCE PRODUCTIVITY
}

\author{
Gary Burtless \\ CRR WP 2013-11 \\ Submitted: May 2013 \\ Released: May 2013
Center for Retirement Research at Boston College
Hovey House
140 Commonwealth Avenue
Chestnut Hill, MA 02467 \\ Tel: 617-552-1762 Fax: 617-552-0191 \\ http://crr.bc.edu
}

Gary Burtless holds the John C. and Nancy D. Whitehead Chair in Economic Studies at the Brookings Institution. The research reported herein was pursuant to a grant from the U.S. Social Security Administration (SSA), funded as part of the Retirement Research Consortium (RRC). The findings and conclusions expressed are solely those of the author and do not represent the views of SSA, any agency of the federal government, the RRC, the Brookings Institution, or Boston College. The author is grateful to Kan Zhang of the Brookings Institution for excellent research assistance.

(C) 2013, Gary Burtless. All rights reserved. Short sections of text, not to exceed two paragraphs, may be quoted without explicit permission provided that full credit, including (C) notice, is given to the source. 


\begin{abstract}
About the Center for Retirement Research
The Center for Retirement Research at Boston College, part of a consortium that includes parallel centers at the University of Michigan and the National Bureau of Economic Research, was established in 1998 through a grant from the Social Security Administration. The Center's mission is to produce first-class research and forge a strong link between the academic community and decision-makers in the public and private sectors around an issue of critical importance to the nation's future. To achieve this mission, the Center sponsors a wide variety of research projects, transmits new findings to a broad audience, trains new scholars, and broadens access to valuable data sources.
\end{abstract}

\author{
Center for Retirement Research at Boston College \\ Hovey House \\ 140 Commonwealth Avenue \\ Chestnut Hill, MA 02467 \\ phone: 617-552-1762 fax: 617-552-0191 \\ e-mail: crr@bc.edu \\ crr.bc.edu
}

Affiliated Institutions:

The Brookings Institution

Massachusetts Institute of Technology

Syracuse University

The Urban Institute 


\begin{abstract}
As the population grows older, an increasing share of the workforce will be past age 60 . Older workers have often been considered less productive than younger ones, raising the issue of whether an aging workforce will also be a less productive one. This paper uses evidence from the monthly Current Population Survey files to shed light on the issue. It documents the rapidly growing role of older workers in the labor market and the steady improvement in their relative earnings. Compared with earlier generations of aged Americans and compared with contemporary prime-age workers, today's elderly are unusually well educated. Their high relative earnings and later retirement are partly explained by this fact. At the same time, the paper offers evidence that more productive workers stay in the workforce longer than less productive ones. Using a standard measure of worker productivity - hourly wages - workers between 60 and 74 are more productive than average workers who are younger. Compared with workers between 25 and 59, the pay premium for older workers is currently between 10 percent and 20 percent of the average wage earned by the younger workers. That pay premium has been increasing for a decade. There is little evidence the aging workforce has hurt productivity.
\end{abstract}




\section{Introduction}

Age-adjusted disability rates have risen, contributing to a decline in the labor force participation of prime-age adults. At the same time, the average age of exit from the workforce has increased. Employment rates of Americans past 60 have edged up since 1990, notwithstanding notable economic weakness after the 2001 recession. The trend toward later retirement is likely to continue.

An unexamined issue is the impact of falling labor force participation rates under age 55 and the trend toward later retirement on the average productivity of the workforce. Increased disability has had a disproportionate impact on the employment of lower wage, less productive workers. The trend toward later retirement may offset or reinforce the impact of higher disability depending on whether later retirement causes the retention of workers with below-average or above-average productivity. This paper uses micro-survey data from the Census Bureau's Current Population Survey (CPS) to determine whether workforce composition effects have increased or reduced the expected productivity of the workforce. It focuses almost entirely on the effects of the changing share and behavior of older workers. Since 2000 we have also seen a sharp drop in labor force participation among Americans under 25, but the effects of that development on productivity will not be examined in this paper.

Workforce composition affects average productivity and earnings in a straightforward way. If the growth in the workforce consists disproportionately of workers with high expected productivity, the increase in productivity and labor compensation will exceed the rate that would occur if workforce composition remained unchanged. The most important determinants of worker productivity are age, educational attainment, and previous work experience. Older, better educated, and more experienced workers are typically more productive and earn higher hourly wages than younger, less educated, and less experienced ones. These relationships are confirmed in cross-sectional surveys of active workers, and they are indirectly supported in lifetime Social Security earnings records, which on average show an increase in workers' lifetime earnings up through early or late middle age (Bosworth, Burtless, and Steuerle, 2000).

An implication of productivity differences by age and education is that the age structure and distribution of educational attainment in the workforce can have noticeable effects on average worker productivity and its rate of change (Dension 1974). The effect of changes in the age profile of the labor force has been the topic of a number of previous studies (see Malmberg 
et al. 2008, Prskawetz et al. 2008, and references cited therein). Both micro- and aggregate time series analyses confirm the effects of a shifting age profile of the workforce on average productivity (Feyrer 2008). A change in the age structure that increases the proportion of workers between 35 and 50 and reduces the fraction of younger or older workers has historically tended to boost productivity gains. An unanswered question is the impact of workforce trends that boost the potential productivity of older workers. Aside from the change in the relative educational attainment of older workers, which has increased in recent years, there are two main trends that affect the potential productivity of older workers (say, workers past age 60). First is the trend in worker disability, which has removed a growing percentage of older men from the labor force and has depressed the growth of old-age labor force participation among women. The effect of this trend has been to remove workers with below-average wages and productivity from the near-aged workforce (Autor and Duggan 2003 and 2006).

A second development that may affect the average productivity of older workers is the trend toward later labor force exit (Burtless 2008). Viewed in isolation this trend increases the proportion of the workforce past age 60 faster than would otherwise be the case. Older workers have historically had lower productivity and wages than prime-age workers, though they have higher productivity than the youngest workers. An unanswered question is whether the trend toward later retirement might affect this historical relationship. The answer depends critically on the identity of workers who exit the workforce at a later age. It may be the case that delayed retirement is occurring more or less proportionally among all groups of aged workers. This would suggest that the productivity of older workers will remain relatively unchanged in comparison with that of younger workers after controlling for the expected educational attainments of older and younger workers. It seems more likely, however, that the trend toward later retirement is not occurring at random but is concentrated among distinctive classes of workers, possibly among workers who have above-average productivity. Were it the case that workers who delay retirement are more productive than average, the historical relationship between the productivity of prime-age and older workers would offer a poor guide to relative wage differentials in the future.

I find little evidence in this paper that the rising importance of older workers has had an adverse impact on average productivity. In comparison with aged worker cohorts in the past, the current generation reaching ages 60 and 70 is very well educated. Men in their early 60 s are 
about as likely as men in their 40s to have a college diploma. For many decades, older men and women had considerably less schooling than younger and mid-career workers. There is also considerable evidence that older workers who remain in the workforce are more productive than the ones who leave. One compelling piece of evidence is that the workers who tend to work longer have better educational credentials. If more productive workers stay in the workforce longer, the average productivity of the older workers who remain employed may compare favorably to the average productivity of the young. In fact, using a standard measure of worker productivity - hourly wages - workers between 60 and 74 are more productive than average workers who are younger. Compared with workers between 25 and 59, the pay premium for older workers is currently between 10 percent and 20 percent of the average wage earned by the younger workers. For more than a decade, the pay premium has been growing.

\section{An aging workforce}

The American workforce is growing older. As the baby boom generation passes middle age and approaches retirement a rising percentage of the employed population will be older than age 60. Figure 1 shows the historical and predicted trend in the share of 16-74 year-old workers who are at least 60 years old. From a recent low point below 6 percent of the working population, the share of employed Americans past 60 has climbed to over 10 percent. It is expected to exceed 13 percent of the employed population by the middle of the next decade. There are two main reasons for the surge in older workers. First, the sheer size of the baby boom generation means that the number of Americans attaining age 60 each year is climbing steeply. Second, labor force participation rates among adults between 60 and 74 have increased strongly, notwithstanding a weak economy. In contrast, participation and employment rates among younger adults, especially those between 16 and 24, have fallen since 2000.

Figure 2 shows changes in the share of the noninstitutionalized 16-74 year-old population that is within indicated five-year age groups. The top panel shows changes in population shares in the 25 years after 1985. The lower panel shows expected changes between 2010 and 2025 , when the population share of 60-74 year-olds will be near its peak. Both panels show the effects of the baby boom generation as it passes through middle age into its retirement years. In 2010, Americans born between 1946 and 1964 were in late middle age or in the first half of their sixties. The large relative size of this generation is reflected in the top panel by sizeable increases in the population shares of 45-64 year-old age groups. In 2025 the youngest member 
of the baby boom generation will turn 61. The share of the 16-74 year-old population that is between 60 and 74 will near its peak. Even if the retirement behavior of the baby boom generation were no different from that of its parents, we should expect to see a surge in the fraction of the active workforce that is 60 to 74 .

There is little prospect that retirement patterns of baby boomers will mirror those of their parents. Labor force participation rates of aged and near-aged Americans have been steadily rising since the early 1990s, a pattern that stands in marked contrast to trends among prime-age and younger adults. Figure 3 shows changes in age-specific labor force participation rates between 1990 and 2012. The first year is selected because it is near the end of a century-long trend toward earlier retirement. The turnaround in retirement trends occurred near the middle of the 1980s among women and shortly after 1990 among men. The top panel of Figure 3 shows participation rate changes, by age, among men. The bottom panel shows the same trends among women. At ages past 60 labor force participation rates have increased among both men and women. At ages below 60 participation rates have declined in every male age group and in about half the female age groups. The female participation rate remains lower than that of men, but the gap narrowed in every age group over the past two decades.

The shifts in labor force participation and in the age structure of the population have combined to boost the fraction of the workforce that is between 60 and 74 . This can be seen in Figure 4, which traces the historical and future share of the 16-74 year-old labor force that is older than age 60. Up through 2012 it is possible to derive estimates of this share using labor force statistics compiled by the BLS. Between the late 1990s and 2012, the fraction of the workforce past 60 increased from about 6 percent to slightly more than 10 percent of labor force participants. Two other sets of estimates are also displayed in the figure. The bottom line shows the trend in the older labor force share under the assumption that the age-and-gender-specific labor force participation rates observed in 1987 remained unchanged through 2012 and will then continue to remain unchanged through 2030. This line therefore shows the pure effect of changes in the population age structure on the expected share of older workers as a percentage of the 16-74 year-old labor force. Note that the workforce share of older adults shrank through the late 1990s. After that the relative share of 60-74 year-olds in the population began to grow. The importance of 60-74 year-olds in the workforce will then rise for about twenty-five years, at which point large numbers of baby boomers will begin leaving this age group. 
The top line in Figure 4 is calculated under the assumption that age-specific labor force participation rates remain unchanged throughout the projection period at the participation rates observed in 2012. Not surprisingly, the line has the same general shape as the lower line. The shapes of both lines are determined by an identical phenomenon, namely, the shifting age composition of the 16-74 year-old population. The vertical distance between the two lines provides an estimate of the effect of labor force participation rate changes between 1987 and 2012. In the year 2012, the difference between the two lines was 3.1 percent, indicating that differences in age-specific participation rates between 1987 and 2012 can explain 3.1 percentage points of the increase in the share of the workforce which is between 60 and 74. Since the total gap between the actual 1987 and 2012 shares was 4.4 percentage points, it follows that nearly three-quarters of the jump in the labor force share of older workers can be explained by shifts in labor force participation rates. Population aging accounts for less than one-third of the change. Note also that the increasing importance of older workers in the labor force, while primarily the result of increasing labor force participation rates among the old, is also traceable to declines in participation rates in younger age groups.

None of the lines in Figure 4 provides a reliable forecast of the future share of 60-74 year-olds in the workforce. The top line in the chart simply shows what that share would be if the intermediate population forecasts of the Social Security Administration are correct and agespecific labor force participation rates remain as they were in 2012. The participation rates of older Americans could continue to increase or the participation rates of younger cohorts could fall further. Either development will increase the share of older workers in the labor force.

\section{Impacts on labor income over the life cycle}

The increase in the old-age labor force participation and the drop in participation at younger ages affect the timing of labor income over the life course. Figure 5 uses information from the March CPS annual income supplements to determine the percentage of 25-74 year-olds who report earning labor income in the indicated calendar year. The figure shows the age pattern of labor income receipt in two different years, 1985 and $2010 .{ }^{1}$ It combines results for both men and women in the CPS sample. Note that the changes in labor force participation rates displayed

\footnotetext{
${ }^{1}$ The ages shown along the horizontal axis in Figure 5 refer to survey respondents' ages at the time of the survey, which took place in March of the following calendar year. Therefore, respondents were one year younger than the indicated year during at least part of the calendar year for which their income was ascertained.
} 
in Figure 3 are mirrored by the statistics on labor income receipt shown in Figure 5. Between 1985 and 2010 there was a decline in the percentage of adults younger than 50 who reported earning labor income, with the biggest declines occurring at the youngest ages. In contrast older adults report substantially higher rates of labor income receipt. The share of adults between 65 and 69 who earned labor income increased from 26 percent to 37 percent between 1985 and 2010. We also see sizeable increases in labor income receipt among 60-64 and 70-74 year-olds.

It is natural to ask whether the additional earners in these older age groups received labor incomes that raised or lowered the average earnings obtained by adults who were gainfully employed. One indicator of a worker's earnings potential is his or her educational attainment. During most of the period analyzed in this paper, older adults had significantly less schooling than prime-age and younger adults. On the other hand, Americans who remain employed into their late 60s and early 70 s tend to have more schooling than their contemporaries who have stopped working. Figure 6 shows labor force participation patterns, by educational attainment group, in the early 1990s and two decades later. The top panel shows tabulations for men between 62 and 74 years old, and the bottom panel shows tabulations for women the same age. During much of the 1990-2010 period age 62 was roughly the average age of labor force exit for men and women who had been career employees in their late 40s and early 50s. Thus, the participation patterns shown in the chart reflect the work choices of people who are past the modal retirement age.

Figure 6 divides the population into seven educational groups, from high school dropouts on the left to doctoral and professional degree holders on the right. The lower line in each panel shows the relationship between labor force participation and educational qualifications in 19911992, and the upper line shows the same relationship nearly two decades later in 2009-2010. In both sets of years the gap between participation rates in the least and the best educated groups is stark. In the early 1990s nearly 60 percent of 62-74 year-old men with doctoral and professional degrees were still labor force participants. In contrast, only 20 percent of male high school dropouts the same age remained in the workforce. The participation-rate gap was smaller in the case of women, but this changed during the next two decades. Note that participation rates in nearly all educational groups increased in the 18-year interval covered by the chart, but the biggest jumps in labor force participation occurred among the best educated women. Older women who hold doctoral and professional degrees saw a 20-percentage-point surge in labor 
force participation. By 2009-2010 slightly more than half of them held jobs or were actively seeking work. At the other end of the educational scale just 15 percent of older women who had failed to complete high school were still in the workforce. Clearly, high levels of schooling are associated with delayed labor force exit. In the case of women, this association has become stronger over time. Bear in mind that the statistics shown in Figure 6 understate the employment gap separating well educated and less well educated groups. Although unemployment rates are typically low among older workers, they are substantially higher among those who have the least schooling. In 2009-2010, for example, the unemployment rate among high school dropouts and older workers whose schooling ended at high school graduation was over 8 percent. Among older Americans with a doctoral or professional degree it was just 2 percent.

The comparative strength of participation rates in well-educated groups may be surprising in view of the steady increase in the proportion of 60-74 year-olds who have a college diploma or an advanced degree. Figure 7 shows longer term trends in the fraction of older Americans who have different levels of schooling. The top panel shows the steady fall in the proportion of the aged and near-aged who have failed to complete high school. The trend between 1985 and 2011 can be ascertained based on tabulations of the monthly CPS outgoing rotation group (ORG) samples (see Schmitt 2003). The trend after 2011 must be predicted. To make a forecast of future schooling levels I used current information about the educational attainment of age groups that will reach age 60 over the next two decades. Since nearly all adults these birth cohorts have completed their schooling the main purpose of the prediction model is to forecast the small future increase in high school completion and the effects of differential mortality and immigration on the proportion of a birth cohort that will hold a high school degree. My prediction model assumes that the future distribution of educational attainment of a given birth cohort will evolve in the manner observed in the monthly CPS samples. Although there is measurement error in the file, birth cohorts tend to see slowly rising educational attainment over time. Even past age 40 the proportion of college graduates tends to increase slowly and the proportion of high school dropouts tends to fall. This pattern may occur as a result added school attendance, nonrandom mortality, and differential net migration of well educated and poorly educated people.

The top panel in Figure 7 shows the dramatic decline in the proportion of 60-74 year-olds with the worst educational credentials. Between 1985 and 2011 the fraction of older men and 
women who failed to obtain a high school diploma fell steeply and steadily. In 1985 more than 40 percent of 60-74 year-olds had failed to obtain a high school degree. By 2011 that fraction fell to 13 percent. My forecast suggests that the proportion of high school dropouts in the older population will continue to fall, though very slowly, through 2030. The lower panel of Figure 7 shows trends in the percentage of 60-74 year-olds who have obtained a college degree or completed four years of college education. Again, the information for 1985 through 2011 was obtained from monthly CPS-ORG files while the forecasts for 2012-2030 were developed using data on college completion rates among birth cohorts that will attain age 60 over the next two decades.

For many decades men were more likely to earn a college degree than women who were the same age. Both sexes saw sizeable increases in college completion over the post-war period through the mid 1970s. After the mid 1970s college completion rates began to lag among men while they continued to rise among women. In recent years women reaching age 30 have been more likely to earn a college degree than men born in the same year. My forecast of future college completion rates among the aged and near-aged reflects these trends. By the middle of the next decade men and women between 60 and 74 will be about equally likely to have a college diploma. At the end of that decade, older women will have a slight edge in college completion compared with men the same age. For men age 60-74 nearly all the rise in the percentage of college degree holders has already occurred. I expect there will be only modest changes in the fraction of older men with a college diploma over the next two decades. Among older women college completion rates will continue to rise, but much more slowly than they did between 1985 and 2011.

Just as important as the absolute schooling attainment of the elderly is the level of their schooling compared with prime age workers. Figures 8 and 9 shed light on this comparison by displaying historical and projected trends in the educational credentials of narrower age groups in the population. An interesting comparison group is the population between 40 and 44, ages when many Americans are approaching the peak earnings of their careers. The two older age groups represented in the charts are 60 to 64 and 70 to 74 years old. Figure 8 shows the trend in the proportion of adults in these three age groups who have failed to complete high school. The top panel presents statistics on women; the lower panel, on men. In 1985 approximately half of all adults between 70 and 74 did not have a high school diploma. By 2010 that proportion 
dipped below 20 percent. In 2030 I expect it will fall below 10 percent. A useful comparison is the percentage of 40-44 year olds who failed to complete high school. In 1985, when almost half of 70-74 year-olds had not completed high school, about 17 percent of 40-44 year-olds had the same educational attainment. By the mid-1990s only about one-tenth of 40-44 year-olds were high school dropouts. This fraction is not expected to change for women, but we have seen a rebound in the dropout rate among 40-44 year-old men.

Figure 9 shows college completion rates in these same age groups. College completion patterns for men and women are broadly similar but far from identical. In 1985 the college completion rate for 40-44 year-old men was about 10 percentage points higher than it was for women the same age. By 2005 the gap had been closed, and by 2010 women in this age group had a higher college completion rate than men. Both in the historical period and in the forecast women between 40 and 44 have higher rates of college degree attainment than women in the two older groups. The gap narrowed between the mid-1990s and 2010, but it did not disappear. This means that for the next twenty years women in their 40s will continue to have an educational advantage over women in their $60 \mathrm{~s}$ and early 70s. On the other hand, many of these older women will have an advantage in terms of work experience. Unlike women in earlier generations, women in the generations soon entering their 60 s and 70 s have spent much of their potential careers in paid employment.

In the 1980s and early 1990s men between 40 and 44 enjoyed a sizeable educational advantage over men in their 60s. In the past decade that advantage has essentially disappeared. Men currently in their 60s are about as likely to have a college degree as men in their early 40s. My forecast of future trends, which is based on observed educational patterns among men who are not yet 40, does not suggest this situation will change in the next two decades. Men in their 60s have essentially closed the educational gap with the prime-age population, and my forecast implies the gap will remain closed for the foreseeable future.

The implications of Figures 7-9 for the educational qualifications of the aged and nearaged should be plain. Between 1985 and 2011 there was a steady improvement in their educational credentials, both absolutely and in comparison to the qualifications of younger cohorts still in their prime working years. The absolute and relative improvement of the qualifications of the aged will be much slower in the future. The percentage of older men in the 
lowest and the highest educational classes will remain largely unchanged, though we will see continued gradual improvement in the educational attainment of older women.

\section{Effects of education on participation and earnings in old age}

The improvement in older Americans' educational attainment, both absolutely and compared with the attainment of younger workers, has improved their job market position. This is especially true for the men and women who actually remain in the workforce because, as we have seen, older Americans who stay attached to the labor force after 62 are much more likely to have received schooling after high school. In view of these facts, a shift in the age-earnings profile of working Americans should not be surprising. Figure 10 shows the relationship between age and the average labor income of people who are employed. I have divided 25-74 year-old men and women into 5-year age groups and calculated the mean wage and net selfemployment income they report in the March CPS annual income supplement. I then divided the average earnings received by working people in each age group by the average earnings of prime-age workers, defined here to include every paid worker between age 35 and 54. The results of these calculations, based on labor incomes received in calendar years 1985 and 2010, are displayed in the top panel of the chart.

At ages between 25 and 54 we see only modest shifts in the relative age-earnings profile. ${ }^{2}$ Starting at age 55, however, there are significant changes in the shape of the earnings profile. Older workers now receive much better compensation compared with their prime-age counterparts. The lower panel shows the percentage-point changes in relative earnings at successive ages. Whereas workers younger than 50 have seen modest declines in their annual earned incomes compared with the earnings received by 35-54 year-olds, workers past 55 have enjoyed impressive earnings gains. Compared with the earnings of an average 35-54 year-old worker, the average worker between 65 and 69 has seen his or her earnings climb 30 percentage points. Workers between 70 and 74 enjoyed a 28-percentage-point gain in their relative

\footnotetext{
${ }^{2}$ There are notable differences between the age-earnings profiles of men and women who work, but the shifts in the male and female age profiles look remarkably similar. In both cases there has been a noticeable upward shift in the relative incomes earned by workers past age 55 and especially past age 65 . One conspicuous difference between the two sexes is that the relative earnings of women in the youngest age group shifted downwards in the 25year span covered by the chart. In the mid-1980s young female workers earned nearly as much as working primeage women. By 2010 young women, like young men, earned significantly less than their prime-age counterparts. An explanation for the change in women's earning patterns is that women are nowadays more likely to work steadily and to experience fewer lengthy interruptions during their careers. Thus, women in mid-career earn a bigger premium for previous experience than was the case in the mid-1980s.
} 
earnings. These gains in the relative position of older workers occurred because such workers saw rapid gains in their absolute earnings. Measured in inflation-adjusted dollars workers between 60 and 64 saw their earnings climb one-third between 1985 and 2010. Workers between 65 and 69 enjoyed an average earnings gain of 84 percent, and working 70-74 year-olds saw their earnings double. In comparison, the average annual earnings of workers between 35 and 54 grew just 18 percent, or 0.7 percent a year. ${ }^{3}$

In part, of course, the relative earnings gains of older workers can be traced to the improvement in their educational attainment compared with younger workers. However, this development does not fully explain their gains. If we separately tabulate the age-earnings profiles of workers within each educational group we see similar, though generally far smaller, income gains among workers in the oldest age categories and small reductions in the relative earnings of workers in most age groups younger than 50. Thus, even accounting for the relative improvement in older workers' educational attainment, older workers have enjoyed faster annual earnings gains than their younger counterparts. This pattern is also evident in the hourly wage data collected in the CPS-ORG surveys. Based on regression results obtained in a standard logwage specification, I find that the age profile of hourly earnings has shifted upward at older ages for both sexes and within all educational groups. In some cases the upward shift is modest and begins relatively late in workers' careers. But this shift is consistently found in a wide variety of statistical specifications (see Appendix Figures 1 and 2).

The overall impact of employment and earnings changes on the labor incomes received by older Americans can be seen in Figure 11. This chart shows the average labor incomes received by all men and women in an age group, whether or not they earn wages or selfemployment income. Because so many people past age 60 are retired and have no earnings, this way of calculating the age-earnings profile depresses the relative position of the oldest age groups. For example, in 1985 working 65-69 year-olds on average earned labor incomes that were 54 percent of the average incomes received by working people between 35 and 54 . In the same year, 65-69 year-olds, including workers and nonworkers, earned an average of just 17 percent of the labor income received by 35-54 year-olds (including both the 35-54 year-olds who worked and those who did not).

\footnotetext{
${ }^{3}$ Nominal earnings are converted into constant dollars using the CPI-U-X1 deflator.
} 
The combined impact of higher labor force participation rates at older ages and higher relative earnings among older workers who hold jobs has produced striking gains in the contribution of earned income to the family incomes of the aged (Bosworth and Burke 2012). The proportional changes in labor incomes received by Americans in the oldest age categories are remarkable. In absolute terms, the real labor earnings of 60-64 year-olds increased 54 percent; the real earnings of 65-69 year-olds increased 164 percent; and the real earnings of 7074 year-olds tripled between 1985 and $2010 .{ }^{4}$ In the same period, the average labor earnings of 35-54 year-olds increased only 14 percent, or slightly faster than 0.5 percent a year. Part of the relative gain enjoyed by older Americans was due to improvements in the relative position of people who held a job. Those jobs produced faster earnings increases than the jobs held by prime-age workers. The remainder of their gains are traceable to increases in the percentage of 60-74 year-olds who are gainfully employed.

Some of the increase in employment at older ages is due to the increase in educational attainment among people in their 60s and early 70s (see Figure 6). If educational gains are the main explanation for increased work in old age, the slowdown in schooling gains among the elderly could weaken one of the main drivers of delayed retirement. To examine the potential effects of schooling shifts on old-age labor supply, I performed the following experiment. Suppose the impact of schooling on labor force participation did not change after 1985. In that case, the labor force participation rate of people within a cell defined by age, gender, and educational attainment would remain unchanged in every year after 1985. The only reason labor force participation in an age group would change is that the mix of educational attainments in the group changes. As should be plain in Figure 6, people with better educational credentials are more likely to work in their 60 s and early 70 s than people who have less schooling. As the population past 60 sees its schooling rise, its participation rate will increase, not because of a

\footnotetext{
${ }^{4}$ Some of the outsize wage and earnings gains of the oldest workers may be the result of a poorly implemented Census Bureau strategy to mask the identity of some older CPS respondents by perturbing their age and sex (Alexander, Davern, and Stevenson 2010). This Census procedure could have resulted in the reclassification of workers in their late 60s as workers in their early 70s. One result might be an overstatement of wages earned by people in their 70s. On the other hand, the procedure is likely to produce an understatement of the average earnings received by respondents in their 60s. Without access to the confidential Census data files it is impossible to estimate the size of the possible error. While the reclassification might result in a misstatement of the distribution of earned income and labor force status among people past 65, a consistent finding of this study is that the relative participation rates and earned incomes of essentially all groups past age 60 have risen in comparison to those of their younger counterparts. Note also that Figures 1 through 4 are not affected by the Census Bureau's reclassification scheme, for they are based on tabulations published by the U.S. BLS, which generates its estimates using files containing accurate data on respondents' sex and age.
} 
change in work behavior (conditional on educational attainment), but because the aged population contains a larger share of highly educated people.

The results of this exercise are displayed in Table 1. The table shows historical and projected labor force participation rate estimates covering the period from 1985 through 2030. The top panel presents estimates for 60-74 year-old men; the bottom panel shows results for women the same age. Column 1 in the table shows the historical path of labor force participation rates in this age group. Columns 2 through 4 show the results of a tabulation I have already described. Column 2 contains estimates of the participation rate under the assumption that agespecific participation rates observed in 1985 would remain unchanged through 2030. In this case, participation rates are held constant for each 5-year age group. Even if the educational mix in an age group changes, the participation rate in the age group would not change. In this scenario, the only factor that causes the participation rate to change is the shift in population shares among the three age groups (60-64, 65-69, and 70-74). The labor force participation rate of 60-74 increases modestly under this scenario, because the population share of 60-64 year-olds increases in relation to the shares of the two older groups.

In column 3 we see the impact of holding age-specific participation rates constant at their level in 2010. All of the entries in column 3 are significantly higher than the corresponding entries in column 2. This means that increases in age-specific participation rates caused almost all of the increase in the actual participation rate between 1985 and 2010; shifts in the population shares of the three older age groups played a very small role. Column 4 shows the impact of the upward shift in participation rates within each age group. After 2010 we do not have information about the actual participation rate. The estimated effect of the 1985-through-2010 increases in age-specific participation rates is simply the difference between two sets of predictions, namely, the predictions shown in columns 2 and 3.

In the tabulations just described, the changing mix of educational attainments has no role in determining the overall participation rate of 60-74 year-olds. Regardless of the education mix in an age group, the entries in columns 2 and 3 are calculated under the assumption that the agespecific participation rate remains unchanged. This assumption is modified in the second experiment, whose results are displayed in columns 5 to 7 . The entries in column 5 and 6 are calculated under the assumption that participation rates remain unchanged within each educational subpopulation in an age group. The participation rate of the full age group will then 
vary if the mix of educational groups in the age group varies. To make these calculations, we divide workers in each age group into four educational classes - less than a high school education, a high school diploma, some schooling after high school, and at least four years of college education.

Column 5 shows predictions of the age 60-74 participation rate when participation rates within each education-and-age cell are held fixed at their observed levels in 1985. Column 6 shows predictions when those participation rates are fixed at their 2010 levels. The results in column 7 show the actual effects of shifts in the participation rates in the education-and-age cells. The results for men are especially interesting. Note that the entries for 1990-2000 are negative. This implies that the actual labor force participation rate of 60-74 year-old men was below the level that would be predicted assuming that 1985's within-cell participation rates remained unchanged. In 2000, for example, the actual participation rate was 36.0 percent, or 1.1 percentage points higher than it was in 1985. However, a naïve prediction based on observed labor force participation rates within each education-and-age cell in 1985 would be that the overall participation rate in 2000 should have risen to 36.4 percent, an estimate that is 0.4 percentage points above the overall participation rate we actually observed. Note that the prediction error when we take account of the changing educational mix, as we do in column 5, is usually smaller than when education is ignored, as it is in the predictions displayed in column 2. This strongly suggests that education gains help account for the upward shift in labor force participation among the elderly. However, based on a simple comparison of the entries in columns 4 and 7, it is clear that the changing education mix explains a much bigger fraction of the upward trend in male participation than it does in the case of women. Thus, the big jump in old-age participation among women is mainly explained by increases in participation rates within age-and-education cells. Shifts in the age and education mix of older women play a smaller role in explaining the rise in their overall participation rates. In contrast, the upward shift in the participation rate of 60-74 year-old males is mainly explained by the rapid rise in their educational attainment. Relatively little of it is explained by increases in participation within the age-and-education group cells.

An identical method can be used to assess the rising percentage of 60-74 year-olds who have labor earnings over the course of a year. The results of this exercise are presented in Table 2. The actual trend in the percentage of 60-74 year-olds with earned incomes is shown in 
column 1. Columns 2 and 3 attempt to determine how this percentage would have varied if the fraction of income recipients in each age group had remained fixed at the levels observed in a given year, either 1985 or 2010 . In the case of men both sets of estimates yield the prediction that the population share of income recipients would have declined. Between 2000 and 2010, however, the actual percentage of 60-74 year-olds climbed faster than would be predicted given the earnings rates observed in 1985. By 2010 the prediction error was 4.2 percentage points, which implies that males' age-specific participation rates increased more than predicted by this naïve forecasting method. The prediction error using this naïve forecasting strategy is even greater for women than it is for men. Between 1985 and 2010 the actual percentage of 60-74 year-old women receiving labor incomes climbed 13.6 percentage points. A naïve prediction method suggests the rise should only have been 1.6 percentage points (column 2) or 1.9 percentage points (column 3). Thus, the naïve forecasting methods explain only 10 to 15 percent of the rise in female participation rates over the period. The remaining 85 to 90 percent is explained by increasing earnings rates within the three age groups.

Our second naïve forecasting strategy is to predict participation rates of 60-74 year-olds under the assumption that participation rates within each age-and-education subpopulation remain constant over the forecasting horizon. Columns 5 and 6 show the predictions generated by this assumption. In the case of men this prediction strategy works much better than the first one; the prediction errors are cumulatively much smaller. In fact, the second forecasting strategy generates a prediction of a bigger increase in the male earning rate than the one we actually observed. Over the 2011-2030 forecasting horizon, the share of 60-74 men with earned income would be roughly 1 percentage point higher under the age-and-education group earnings rates observed in 1985 than under the earnings rates observed in 2010. In other words, when we take account of the sharp increase in the educational attainment of older men, we can explain essentially all the upward trend in the share of older men who have earned income. The "surprise" is that the share of men with earnings has not risen even more. In the case of women the prediction error using the second naïve forecasting method reduces but does not eliminate the errors produced by the first forecasting method. Using 1985 earnings patterns we would predict that the share of women earning labor incomes should have increased 6.5 percentage points (column 5). The actual rise was 13.6 percentage points. Thus, a bit less than half the increase is explained by shifts in the population shares of different age groups and increases in the 
percentage of women in each age group who have advanced schooling. The other half of the increase is traceable to increases in earnings rates within age-and-education group cells, in other words, to a change in women's propensity to work given their educational attainment.

These analytical methods can also be applied to evaluate the share of earned income that is received by 60-74 year-old workers. The fraction of all labor income received by $25-74$ yearold workers that is received by workers between 60 and 74 has increased sharply in recent years. Based on micro-census records from the March CPS, I estimate that the share of male earnings received by 60-74 year-olds increased from 7.3 percent in 2000 to 12.7 percent in 2010. Among women earners, the share increased from 5.8 percent of total female earnings in 2000 to 11.7 percent of earnings in 2010 (see column 1 in Table 3). The magnitude of these gains is partly explained by the rising share of older workers in the labor force, partly by their increasing levels of work, and partly by improvements in their relative earnings if they do work. In Table 3 I use the two naïve forecasting methods just described to determine how much of the rise in older workers' earnings share can be explained by population aging and changes in the share of the well educated population in different age groups.

Note that the calculations in Table 3 take account of population and education shifts in the entire 25-74 year-old population, not just in the 60-74 year-old population. The reason is that we are trying to explain why the share of all earned income received by aged workers has changed. This calculation depends on earnings changes in the 25-59 year-old population as well as in the population between 60 and 74 . The predictions shown in column 2 of the table rely on the assumption that the relative earnings of a person in each age group will remain fixed over the forecasting horizon. That is, if the ratio of earned income of an average person age 25-29 to that of an average person 45-49 was 0.76 in 1985, that ratio would be maintained over the forecasting period. ${ }^{5}$ Column 3 shows the result of the same forecasting method if the average earnings ratios were maintained at their 2010 observed levels. Obviously, both these forecasts account for only a small portion of the actual rise in the percentage of earned income that is received by the elderly. This finding is not surprising in light of the results presented in Figure 11, which show a sizeable upward shift in the relative earnings received by aged and near-aged Americans.

\footnotetext{
${ }^{5}$ Note that the "average person" reflects nonearners in the age group as well as the people who have earnings. In other words, the average earned income ratios for each age group are calculated using the group-average amount of earnings, including $\$ 0$ amounts for nonearners in the group.
} 
Columns 5 and 6 show predictions produced under the slightly less naïve assumption that the relative earnings of people in each age-and-education group remain fixed at their observed levels, either in 1985 or 2010. These predictions are also displayed as the lower and higher lines, respectively, in Figure 12. The line connecting the two prediction lines shows the actual year-by-year percentage of labor income received by older workers. These estimates are the same ones shown in column 1 of Table 3. The prediction errors using the slightly-less-naive model are considerably smaller than those produced when only shifts in the age composition of the population are taken into account. To see the implications of these results, consider the earnings share of older male workers in 1985 and 2010. Their actual earnings share increased 4.9 percentage points (column 1). If the age-specific earnings levels had remained unchanged, the earnings share of older men would have increased 1.0 percentage points because their population share increased (column 2). If the age-and-education earnings ratios had remained unchanged, the earnings share of older men would have increased 3.0 percentage points (column 5). Thus, the actual earnings share of older men increased 1.9 percentage points more than can be easily explained by their share in the population and shifts in the educational attainment of the different age groups in the population. Among women, the prediction errors are bigger. Accounting for both the shift in population shares and the improvement in older women's educational attainment compared with younger groups, 3.4 percentage points out of the 5.4percentage-point increase in older women's earnings share is unexplained. The increased population share of older women and the improvement in their relative schooling accounts for just 2.0 percentage points of the increase in their earnings share (column 5). Stated another way, an unexpected surge in older women's earnings per worker or labor force engagement explains most of the rise in their earnings share.

The predictions shown in column 6 and displayed in the upper lines of Figure 12 indicate that, even if employment and earnings patterns of older workers do not change during the next two decades, the share of all labor income received by older workers will continue to rise through about 2025. The predictions account for relative population growth in younger and older age categories and for the shifts in the expected educational attainments of the population in different age groups. At their peak in importance, 60-74 year-old men will account for about 16 percent of male earnings and 60-74 year-old women for about 141/2 percent of female earnings. Of course, the upward shift in old-age labor supply could reverse, or we could see a 
rebound in the participation rates and relative earnings of the young. Either development could reduce the earnings share of older workers. Both among older men and women, however, the trend of earnings and work effort has clearly produced an upward shift in their current and expected contribution to U.S. labor input.

\section{Impacts of aging and delayed retirement on worker productivity}

The discussion so far suggests that older workers have become more important in the job market for two main reasons. First, they represent a larger share of the potential workforce; their population size is growing compared with that of younger age groups. Second, both their average earnings and their labor force participation have increased compared with that of adults in younger age groups. My analysis suggests there is a simple explanation for much of the increase in older adults' relative earnings and labor force engagement. Aged Americans are now significantly better educated compared with nonaged adults than was the case in the mid-1980s. As older people's educational credentials have improved they have gained access to better jobs and have stayed in the workforce longer. In addition, tabulations of wage and annual income data in the CPS suggest older Americans' employment and earnings gains have been faster, especially in the case of women, than would be predicted solely on the basis of their improved schooling. This implies there have been shifts in worker behavior (workers now prefer to stay longer in the job market) or shifts in employer preferences and needs (employers now demand more of the skills that aging workers can supply).

Have the trends to an older population and toward a workforce population with a bigger appetite for work in old age led to a reduction in average worker productivity? This depends on the measure of productivity one prefers. Many economists believe productivity is best reflected at the individual level by the total compensation a worker receives. No publicly available data set contains reliable cross-section information on the total compensation received by individual workers. Money wages, which are reported in a number of household surveys, offer an imperfect proxy for compensation. The correlation between money wages and compensation is high, but it is not 1.00. Nonetheless, money wages undoubtedly provide the best single indicator of worker productivity at the individual level.

Estimates of average money wages within the prime-age working population and in older working age groups are displayed in the top two panels of Tables 4 and 5. Table 4 provides earnings estimates for men, and Table 5 presents the same estimates for women. The top panel 
in the tables shows trends in real average hourly earnings of workers who have a reported or an inferred wage in the CPS-ORG files. Real wages have increased in all the age groups included in the table, but they have risen faster in older age groups than in the prime-age workforce. The ratio of the average hourly wage received by 60-74 year-old workers to that earned by 35-54 year-old workers was about 86 percent for both male and female workers in 1985. The wage ratio has improved in favor of older workers by a sizeable margin since that year, especially in the decade after 2000. In 2010 the average hourly wage of men between 60 and 74 was 99 percent of that earned by men between 35 and 54. This indicator of worker productivity implies that working men past 60 are approximately as productive as their prime-age counterparts. One interpretation of this result is that the enormous expansion of the older male workforce has offered the equivalent of an equal-size enlargement in the pool of prime-age workers. Older female workers have reduced the hourly wage gap with their prime-age counterparts, but their hourly pay still trails that of prime-age working women by about 9 percent.

The middle panel in Tables 4 and 5 shows trends in average real weekly earnings. These numbers also show older workers closing the pay gap with prime-age workers, but a sizeable difference remains. In 2010, on a weekly basis, male wage earners received 8 percent less pay than their prime-age counterparts; female workers received 17 percent less pay. The gap in weekly pay remains large because older workers are employed fewer hours a week than primeage workers.

The top two panels of Tables 4 and 5 show the labor incomes earned by wage and salary workers. Older workers are more likely to be self-employed than prime-age workers, so the wage statistics provide a less reliable indicator of their average productivity than they do in the case of younger workers. The annual income supplement in the March CPS file allows us to develop a more comprehensive measure of labor earnings, including net self-employment income as well as wage earnings. The bottom panel of Tables 4 and 5 shows estimates of the average earnings - wages plus net self-employment income - reported by workers in the indicated age groups. The annual earnings statistics show older workers closing but not eliminating the pay gap with prime-age workers. In 1985 the combined wage and selfemployment income of 60-74 year-old workers was 70 percent of the corresponding amount reported by working 35-54 year-olds. A quarter century later older working men earned an average of $\$ 0.92$ for every $\$ 1.00$ earned by prime-age male workers, and older working women 
earned $\$ 0.88$ for every $\$ 1.00$ earned by prime-age working women. As we have seen, a large part of the explanation for the shrinking pay gap is that older men and women have seen improvements in their schooling relative to that of prime-age workers.

Tables 4 and 5 emphasize a common type of comparison: How productive are older workers compared with workers who are in the prime years of their careers? Of course, the nonaged workforce does not consist solely of prime-age workers. It also contains new labor force entrants and other groups that receive substantially less pay than prime-age workers. Suppose we compare older workers' pay to that received by a broader cross-section of younger workers. Figures 13 and 14 show the results of this comparison. The comparison group I use is workers who are between 25 and 59 years old. It obviously excludes the youngest workers, whose low earnings would bring down the average. Figure 13 compares the hourly and weekly pay of wage earners in the older and younger groups. The average hourly pay of older workers has been comparable to that earned by younger workers over the entire period covered by this analysis (see the top panel in the chart). Since 2000 the relative pay of older workers has improved. Both older men and older women now earn more per hour than their 25-59 year-old counterparts. Because older workers typically work for fewer hours in an average week, their weekly wages were lower than the weekly earnings of 25-59 year-old workers. Between 2000 and 2011 the weekly pay gap steadily shrank, and men between 60 and 74 currently earn the same weekly wages as younger male workers. Older women now earn an average of 11 percent less than younger female workers. In both cases the pay differential is much smaller than the one seen in the recent past. Between 1985 and 1999 older women received weekly wages that averaged 27 percent below the average weekly wage paid to a 25-59 year-old woman. An implication of this set of findings is that the surge in the availability of older workers has not harmed their job prospects. On the contrary, their relative position has improved.

Figure 14 shows the trend in the annual earned incomes of 60-74 year-old workers compared with 25-59 year-olds. In 1985 older men earned about 20 percent less over the course of a year than men in the younger age group. By 2008 the average annual earnings of the two groups were the same. This achievement is more impressive when we consider the job market situation facing the two groups of workers. Most younger workers are near the beginning or in the middle of their careers. Few anticipate ending their careers any time soon. In contrast, most workers between 60 and 74 are in the twilight of their careers. An overwhelming share of all 
retirements occurs between ages 60 and 74. Many of the earnings amounts reported by 60-74 year-old workers are therefore lower than the workers' usual rate of pay. If they had not retired in the middle the year, their annual pay would have been higher. Nonetheless, by 2008 men between 60 and 74 earned the same average annual pay as men at the beginning and in the middle of their careers.

The annual earnings gains of older women are comparable to those achieved by older men. In one respect they are much more impressive. Whereas men between 25 and 59 saw their real annual earnings grow just 10 percent between 1985 and 2010, women the same age enjoyed earnings gains of 50 percent. In order to leave the pay gap unchanged, women past 60 had to obtain pay increases of 50 percent. In fact, women between 60 and 74 saw their annual earnings grow 87 percent, reducing the gap in annual pay between younger and older workers by 20 percentage points.

\section{Conclusion}

If worker productivity has been harmed by the surge of older workers into the labor force the fact is not evident in the earnings statistics for the elderly themselves. Using one standard benchmark for measuring individual worker productivity_hourly wages — workers between 60 and 74 are currently paid more than an average worker who is between 25 and 59. The hourly pay premium for older men was about 20 percent in 2010. For women it was about 10 percent. Other benchmarks show a somewhat less favorable picture, but all of them show considerable improvement in the relative position of aged workers compared with the nonaged. None of the indicators of male productivity suggest that older male workers are less productive than average workers who are between 25 and 59.

The expectation that older workers will reduce average productivity may be fueled by the perception that the aged are less healthy, less educated, less up-to-date in their knowledge, and more fragile than the young. While all these images of the elderly are accurate to some degree, they do not necessarily describe the people who choose or who are permitted to remain in paid employment at older ages. This paper has shown that there are enormous differences between the labor force participation rates of older Americans depending on their level of schooling. People with limited education have low employment rates in old age. People with college and advanced degrees tend to remain in the workforce longer. If less productive workers selectively exit the workforce at younger ages, the average productivity of the older workers who remain 
may compare favorably to the average productivity of the young. A surge in the percentage of the potential workforce that is old may simply increase the proportion of the workforce that consists of comparatively skilled older workers.

In recent years the effects of selective exit from the workforce have been compounded by changes in the distribution of educational attainment across the population. As recently as 1985 Americans between 60 and 74 had far less schooling than Americans in their prime working years. Nearly half of men and women between 70 and 74 did not have a high school diploma. Only about 10 percent of them had a college degree. In contrast, less than a fifth of men and women in their 40 s were high school dropouts and nearly a quarter had a college degree. The educational gap has narrowed considerably for women and virtually disappeared among men. Between 2005 and 2010 the percentage of men with a college degree was higher among 60-64 year-olds than it was among 40-44 year-olds. The gap in schooling has not yet disappeared among women, but it is shrinking. By 2020 I expect that the proportion of high school dropouts will be the same among women in their 40s, 60s, and early $70 \mathrm{~s}$.

The trends in educational attainment help account for two notable developments in oldage labor supply. First, participation and employment rates at older ages have increased, in some measure because better educated workers tend to stay in the workforce longer. This factor by itself explains most of the increase in old-age labor supply among men. It explains about half the increased percentage of older women who have earnings. Second, the average earnings of older workers have improved compared with the earnings of younger workers. Although much of this improvement can be explained by changes in educational attainment of Americans between 60 and 74 , some of it cannot be.

These trends in combination have sharply increased the percentage of earned income that is received by workers between 60 and 74. Between 2000 and 2010 their earnings share increased 5 percentage points of the total earned income received by 25-74 year-old U.S. workers. In 2000 men between 60 and 74 received 7.3 percent of labor income earned by all men between 25 and 74. By 2010, that fraction had increased to 12.7 percent. Some of the change can be explained by population growth, but much more of it was the result of increasing educational attainment among men between 60 and 74. If earnings patterns among age and education groups remain unchanged over the next two decades, we should expect that by 2025 
men between 60 and 74 will earn about 16 percent of all the labor income received by 25-74 year-old men.

The productivity effect of the growing population of aged workers has been benign for two reasons. Less productive workers tend to drop out of the labor force at younger ages, leaving more productive workers employed at older ages. In addition, the nation's past investments in schooling combined with flagging educational investments in the recent past have given us a generation of aged workers that is relatively well educated compared with prime-age Americans. The generation currently entering its $60 \mathrm{~s}$ and $70 \mathrm{~s}$ is better educated than previous generations, giving many of its members powerful advantages in holding on to their jobs or finding new ones. If older workers' larger role in the labor force has had an adverse impact on worker productivity, it is hard to see in the wage statistics. 


\section{References}

Alexander, J. Trent, Michael Davern, and Betsey Stevenson. 2010. "Inaccurate Age and Sex Data in the Census PUMS Files: Evidence and Implications." Working paper 15703. (Cambridge, MA: NBER).

Autor, David H., and Mark G. Duggan. 2003. "The rise in the disability rolls and the decline in unemployment." Quarterly Journal of Economics 118(1): 157-205.

Autor, David H., and Mark G. Duggan. 2006. "The Growth in the Social Security Disability Rolls: A Fiscal Crisis Unfolding.” Journal of Economic Perspectives 20(3): 71-96.

Bosworth, Barry P., and Kathleen Burke. 2012. "Changing Sources of Income Among the Aged Population,” Working Paper 2012-27 (Chestnut Hill, MA: Center for Retirement Research at Boston College).

Bosworth, Barry, Gary Burtless, and Eugene Steuerle. 2000. "Lifetime Earnings Patterns, the Distribution of Future Social Security Benefits, and the Impact of Pension Reform." Social Security Bulletin 63(4): 74-98.

Burtless, Gary. 2008. "The Rising Age at Retirement in Industrial Countries," Working Paper 2008-6, (Chestnut Hill, MA: Center for Retirement Research at Boston College).

Denison, Edward F. 1974. Accounting for United States Economic Growth, 1929-1969. (Washington, DC: Brookings Institution).

Feyrer, James. 2008. "Aggregate Evidence on the Link between Age Structure and Productivity." Population and Development Review 34: 78-99.

Malmberg, Bo, Thomas Lindh, and Max Halvarsson. 2008. "Productivity Consequences of Workforce Aging: Stagnation or Horndal Effect?" Population and Development Review 34: 238-256.

Prskawetz, Alexia, Thomas Fent, and Ross Guest. 2008. "Workforce Aging and Labor Productivity: The Role of Supply and Demand for Labor in the G7 Countries" Population and Development Review 34: 298-323.

Schmitt, John. 2003. "Creating a Consistent Hourly Wage Series from the Current Population Survey's Outgoing Rotation Group, 1979-2002.” Working paper. (Washington: Center for Economic and Policy Research). 
Table 1. Labor Force Participation Rates of 60-74 Year-olds under Alternative Assumptions, $1985-2030$

Percent of noninstitutionalized population age 60-74

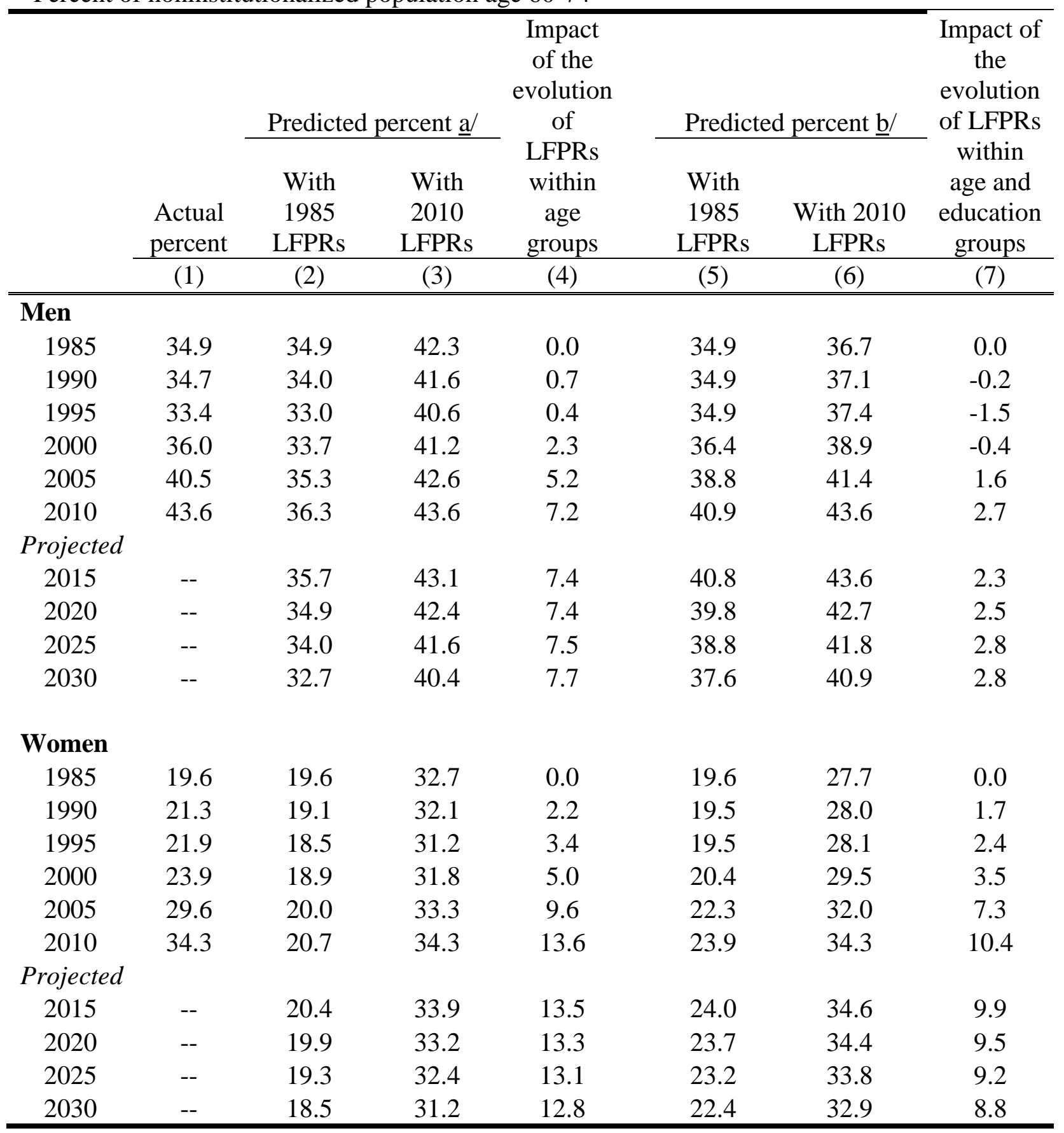

a/ Holding constant the LFPR patterns observed within age and gender cells in the indicated year.

$\underline{b}$ / Holding constant the LFPR patterns observed within age, gender, and education cells in the indicated year. Source: Author's tabulations of 1985-2011 CPS-ORG files and Social Security Administration population projections as explained in the text. 
Table 2. Percent of 60-74 Year-olds Who Had Labor Income in the Previous Calendar Year under Alternative Assumptions, 1985-2030

Percent of noninstitutionalized population age 60-74

\begin{tabular}{|c|c|c|c|c|c|c|c|}
\hline & \multirow{3}{*}{$\begin{array}{c}\begin{array}{c}\text { Actual } \\
\text { percent }\end{array} \\
(1)\end{array}$} & \multirow{2}{*}{\multicolumn{3}{|c|}{ 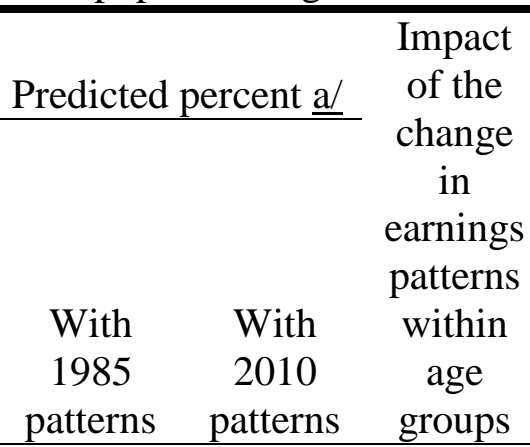 }} & \multicolumn{2}{|c|}{ Predicted percent a/ } & \multirow{3}{*}{$\begin{array}{l}\text { Impact of } \\
\text { the change } \\
\text { in } \\
\text { earnings } \\
\text { patterns } \\
\text { within age } \\
\text { and } \\
\text { education } \\
\text { groups } \\
\text { (7) }\end{array}$} \\
\hline & & & & & $\begin{array}{c}\text { With } \\
1985 \\
\text { patterns }\end{array}$ & $\begin{array}{c}\text { With } \\
2010 \\
\text { patterns }\end{array}$ & \\
\hline & & (2) & (3) & (4) & (5) & (6) & \\
\hline \multicolumn{8}{|l|}{ Men } \\
\hline 1985 & 42.4 & 42.4 & 47.0 & 0.0 & 42.4 & 41.2 & 0.0 \\
\hline 1990 & 42.6 & 41.5 & 46.3 & 1.1 & 42.8 & 41.9 & 0.0 \\
\hline 1995 & 40.5 & 40.7 & 45.6 & -0.2 & 43.1 & 42.5 & -2.4 \\
\hline 2000 & 44.1 & 41.7 & 46.4 & 2.4 & 44.9 & 44.1 & -0.7 \\
\hline 2005 & 46.0 & 43.0 & 47.5 & 3.0 & 47.2 & 46.2 & -1.1 \\
\hline 2010 & 48.6 & 44.4 & 48.6 & 4.2 & 49.7 & 48.6 & -1.0 \\
\hline \multicolumn{8}{|l|}{ Projected } \\
\hline 2015 & -- & 43.4 & 47.9 & 4.5 & 49.1 & 48.3 & -1.2 \\
\hline 2020 & -- & 42.4 & 47.0 & 4.6 & 48.1 & 47.2 & -1.0 \\
\hline 2025 & -- & 41.5 & 46.3 & 4.8 & 47.0 & 46.3 & -0.7 \\
\hline 2030 & -- & 40.4 & 45.3 & 5.0 & 46.1 & 45.6 & -0.7 \\
\hline \multicolumn{8}{|l|}{ Women } \\
\hline 1985 & 24.2 & 24.2 & 35.9 & 0.0 & 24.2 & 29.6 & 0.0 \\
\hline 1990 & 26.4 & 23.7 & 35.3 & 2.7 & 24.9 & 30.4 & 2.0 \\
\hline 1995 & 26.8 & 23.0 & 34.5 & 3.8 & 24.5 & 30.4 & 2.4 \\
\hline 2000 & 29.8 & 23.7 & 35.2 & 6.2 & 26.1 & 32.4 & 4.0 \\
\hline 2005 & 34.4 & 24.9 & 36.7 & 9.5 & 28.5 & 35.2 & 6.1 \\
\hline 2010 & 37.8 & 25.8 & 37.8 & 12.0 & 30.7 & 37.8 & 7.1 \\
\hline \multicolumn{8}{|l|}{ Projected } \\
\hline 2015 & -- & 25.6 & 37.7 & 12.1 & 31.2 & 38.6 & 6.5 \\
\hline 2020 & -- & 25.0 & 36.8 & 11.9 & 30.6 & 38.4 & 6.2 \\
\hline 2025 & -- & 24.2 & 36.0 & 11.8 & 30.1 & 37.9 & 5.9 \\
\hline 2030 & -- & 23.4 & 35.0 & 11.6 & 29.4 & 37.3 & 5.6 \\
\hline
\end{tabular}

a/ Holding constant the earnings patterns observed within age and gender cells in the indicated year.

b/ Holding constant the earnings patterns observed within age, gender, and education cells in the indicated year. Source: Author's tabulations of 1986-2011 March CPS files and Social Security Administration population projections as explained in the text. 
Table 3. Percent of Labor Income Earned by Workers Who Are 60-74 Years Old under Alternative Assumptions, 1985-2030 al

Percent of earnings

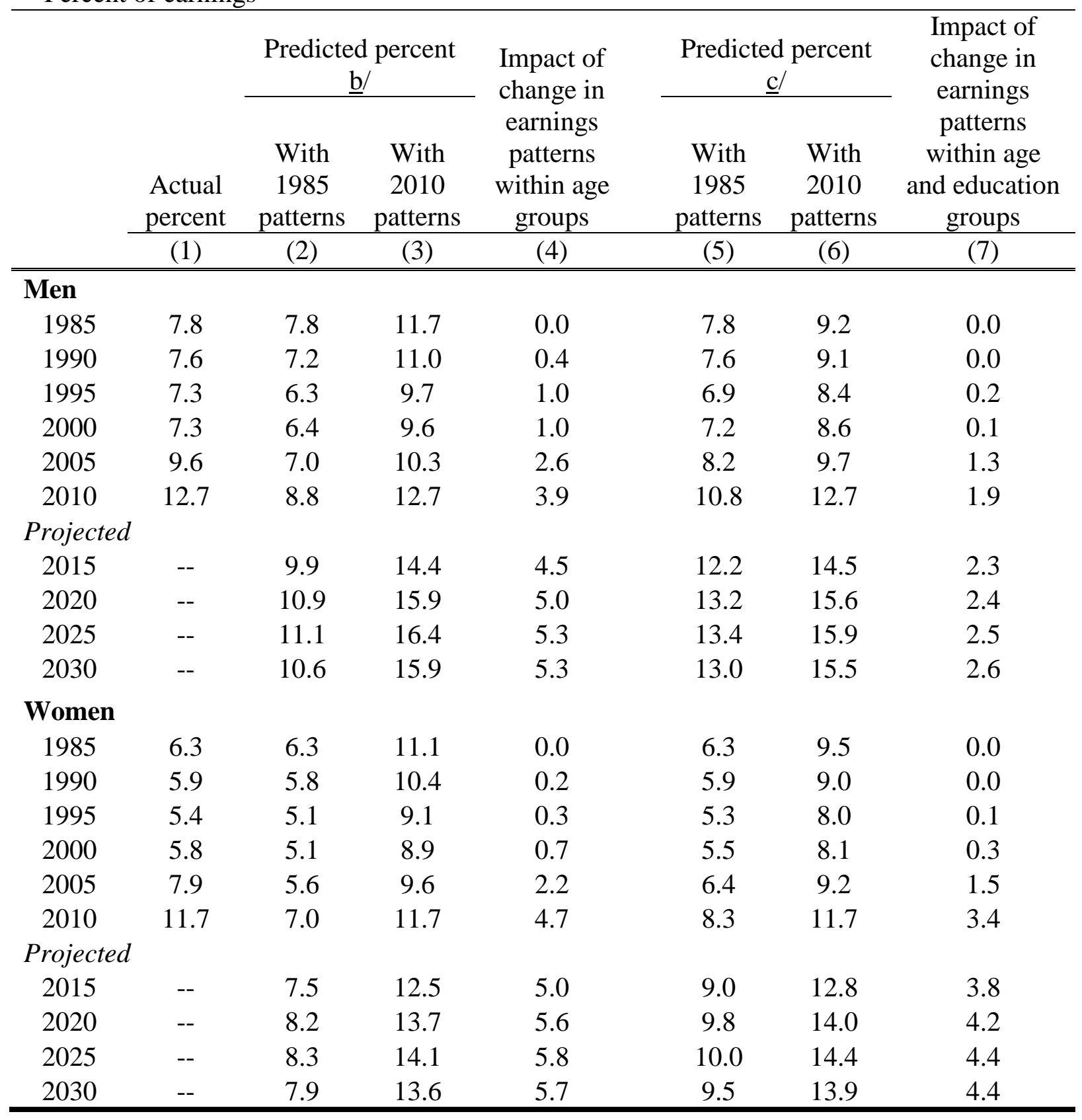

a/ "Total earned income" refers to all wage and net self-employment income received by persons of the same gender who are between 25 and 74 years old.

b/ Holding constant the earnings patterns observed within age and gender cells in the indicated year.

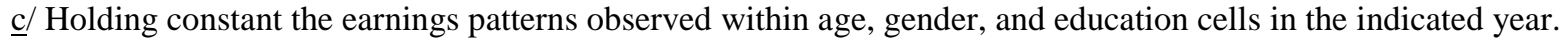

Source: Author's tabulations of 1986-2011 March CPS files and Social Security Administration population projections as explained in the text. 
Table 4. Average Wages and Earned Incomes of Men Who Receive Labor Incomes, by Age Group, 1985-2010

Labor income measured in constant 2010 dollars

\begin{tabular}{|c|c|c|c|c|c|c|}
\hline & $\begin{array}{c}35-54 \\
(1)\end{array}$ & $\begin{array}{c}60-64 \\
(2)\end{array}$ & $\begin{array}{c}\text { 65-69 } \\
(3)\end{array}$ & $\begin{array}{c}\text { 70-74 } \\
(4) \\
\end{array}$ & $\begin{array}{c}60-74 \\
(5) \\
\end{array}$ & $\begin{array}{c}\text { Ratio of } \\
\text { average } \\
\text { earnings }(\%) \\
(5) /(1)\end{array}$ \\
\hline \multicolumn{7}{|c|}{ Average hourly earnings } \\
\hline 1985 & $\$ 24.10$ & $\$ 22.22$ & $\$ 19.12$ & $\$ 15.15$ & $\$ 20.94$ & 86.9 \\
\hline 1990 & 23.79 & 22.72 & 17.57 & 15.11 & 20.73 & 87.2 \\
\hline 1995 & 23.51 & 22.25 & 18.94 & 17.08 & 20.78 & 88.4 \\
\hline 2000 & 24.54 & 22.62 & 18.72 & 18.25 & 21.05 & 85.8 \\
\hline 2005 & 24.77 & 24.57 & 21.48 & 18.73 & 23.16 & 93.5 \\
\hline 2010 & 25.83 & 26.69 & 24.26 & 21.69 & 25.55 & 98.9 \\
\hline $\begin{array}{r}\text { Percent change, } \\
1985-2010\end{array}$ & 7.2 & 20.1 & 26.9 & 43.2 & 22.0 & \\
\hline \multicolumn{7}{|c|}{ Average weekly earnings } \\
\hline 1985 & $\$ 984$ & $\$ 866$ & $\$ 602$ & $\$ 403$ & $\$ 769$ & 78.1 \\
\hline 1990 & 1,031 & 926 & 599 & 459 & 802 & 77.8 \\
\hline 1995 & 1,027 & 901 & 644 & 498 & 787 & 76.7 \\
\hline 2000 & 1,106 & 961 & 672 & 601 & 840 & 75.9 \\
\hline 2005 & 1,095 & 1,026 & 826 & 672 & 937 & 85.6 \\
\hline 2010 & 1,087 & 1,084 & 907 & 730 & 1,002 & 92.2 \\
\hline $\begin{array}{r}\text { Percent change, } \\
1985-2010\end{array}$ & 10.5 & 25.2 & 50.7 & 81.1 & 30.4 & \\
\hline \multicolumn{7}{|c|}{ Average annual earned income } \\
\hline 1985 & $\$ 51,846$ & $\$ 44,557$ & $\$ 25,979$ & $\$ 21,063$ & $\$ 36,439$ & 70.3 \\
\hline 1990 & 52,310 & 42,471 & 30,767 & 25,250 & 36,952 & 70.6 \\
\hline 1995 & 53,822 & 47,490 & 37,271 & 29,356 & 41,628 & 77.3 \\
\hline 2000 & 59,537 & 51,512 & 39,190 & 32,247 & 45,083 & 75.7 \\
\hline 2005 & 58,524 & 58,713 & 48,286 & 37,736 & 52,911 & 90.4 \\
\hline 2010 & 55,315 & 55,722 & 46,306 & 37,345 & 50,770 & 91.8 \\
\hline $\begin{array}{r}\text { Percent change, } \\
1985-2010\end{array}$ & 6.7 & 25.1 & 78.2 & 77.3 & 39.3 & \\
\hline
\end{tabular}

Source: Author's estimates derived from the 1985-2010 CPS-ORG files for hourly and weekly earnings and from the March 1986-2011 CPS annual income supplement for annual earned incomes. 
Table 5. Average Wages and Earned Incomes of Women Who Receive Labor Incomes, by Age Group, 1985-2010

Labor income measured in constant 2010 dollars

\begin{tabular}{|c|c|c|c|c|c|c|}
\hline & $\begin{array}{c}\mathbf{3 5 - 5 4} \\
(1) \\
\end{array}$ & $\begin{array}{c}60-64 \\
(2) \\
\end{array}$ & $\begin{array}{c}65-69 \\
(3) \\
\end{array}$ & $\begin{array}{c}70-74 \\
(4) \\
\end{array}$ & $\begin{array}{c}60-74 \\
(5) \\
\end{array}$ & $\begin{array}{c}\text { Ratio of } \\
\text { average } \\
\text { earnings }(\%) \\
(5) /(1) \\
\end{array}$ \\
\hline \multicolumn{7}{|c|}{ Average hourly earnings } \\
\hline 1985 & $\$ 15.21$ & $\$ 13.79$ & $\$ 12.13$ & $\$ 10.77$ & $\$ 13.12$ & 86.2 \\
\hline 1990 & 16.41 & 14.16 & 12.26 & 11.27 & 13.33 & 81.2 \\
\hline 1995 & 17.33 & 14.83 & 13.25 & 11.92 & 14.06 & 81.1 \\
\hline 2000 & 18.58 & 15.93 & 13.91 & 12.28 & 14.97 & 80.6 \\
\hline 2005 & 19.45 & 18.04 & 15.66 & 14.23 & 17.03 & 87.6 \\
\hline 2010 & 20.47 & 19.72 & 17.23 & 15.72 & 18.72 & 91.4 \\
\hline $\begin{array}{r}\text { Percent change, } \\
1985-2010\end{array}$ & 34.6 & 43.0 & 42.1 & 46.0 & 42.7 & \\
\hline \multicolumn{7}{|c|}{ Average weekly earnings } \\
\hline 1985 & $\$ 560$ & $\$ 487$ & $\$ 337$ & $\$ 256$ & $\$ 430$ & 76.8 \\
\hline 1990 & 629 & 493 & 362 & 293 & 436 & 69.2 \\
\hline 1995 & 668 & 520 & 373 & 310 & 455 & 68.2 \\
\hline 2000 & 733 & 578 & 427 & 328 & 509 & 69.5 \\
\hline 2005 & 765 & 677 & 500 & 387 & 601 & 78.5 \\
\hline 2010 & 786 & 724 & 555 & 441 & 655 & 83.3 \\
\hline $\begin{array}{r}\text { Percent change, } \\
1985-2010\end{array}$ & 40.3 & 48.8 & 64.7 & 72.5 & 52.3 & \\
\hline \multicolumn{7}{|c|}{ Average annual earned income } \\
\hline 1985 & $\$ 25,603$ & $\$ 21,020$ & $\$ 14,164$ & $\$ 9,383$ & $\$ 17,987$ & 70.3 \\
\hline 1990 & 29,500 & 22,544 & 15,982 & 12,672 & 19,331 & 65.5 \\
\hline 1995 & 31,968 & 24,724 & 16,675 & 13,458 & 20,898 & 65.4 \\
\hline 2000 & 36,182 & 28,779 & 20,815 & 16,570 & 24,840 & 68.7 \\
\hline 2005 & 38,089 & 31,707 & 27,028 & 20,041 & 29,109 & 76.4 \\
\hline 2010 & 38,350 & 35,794 & 31,426 & 26,169 & 33,609 & 87.6 \\
\hline $\begin{array}{r}\text { Percent change, } \\
1985-2010\end{array}$ & 49.8 & 70.3 & 121.9 & 178.9 & 86.9 & \\
\hline
\end{tabular}

Source: Author's estimates derived from the 1985-2010 CPS-ORG files for hourly and weekly earnings and from the March 1986-2011 CPS annual income supplement for annual earned incomes. 
Figure 1. Percent of Employed Population Older than 60 and Older than 65, 1985-2040

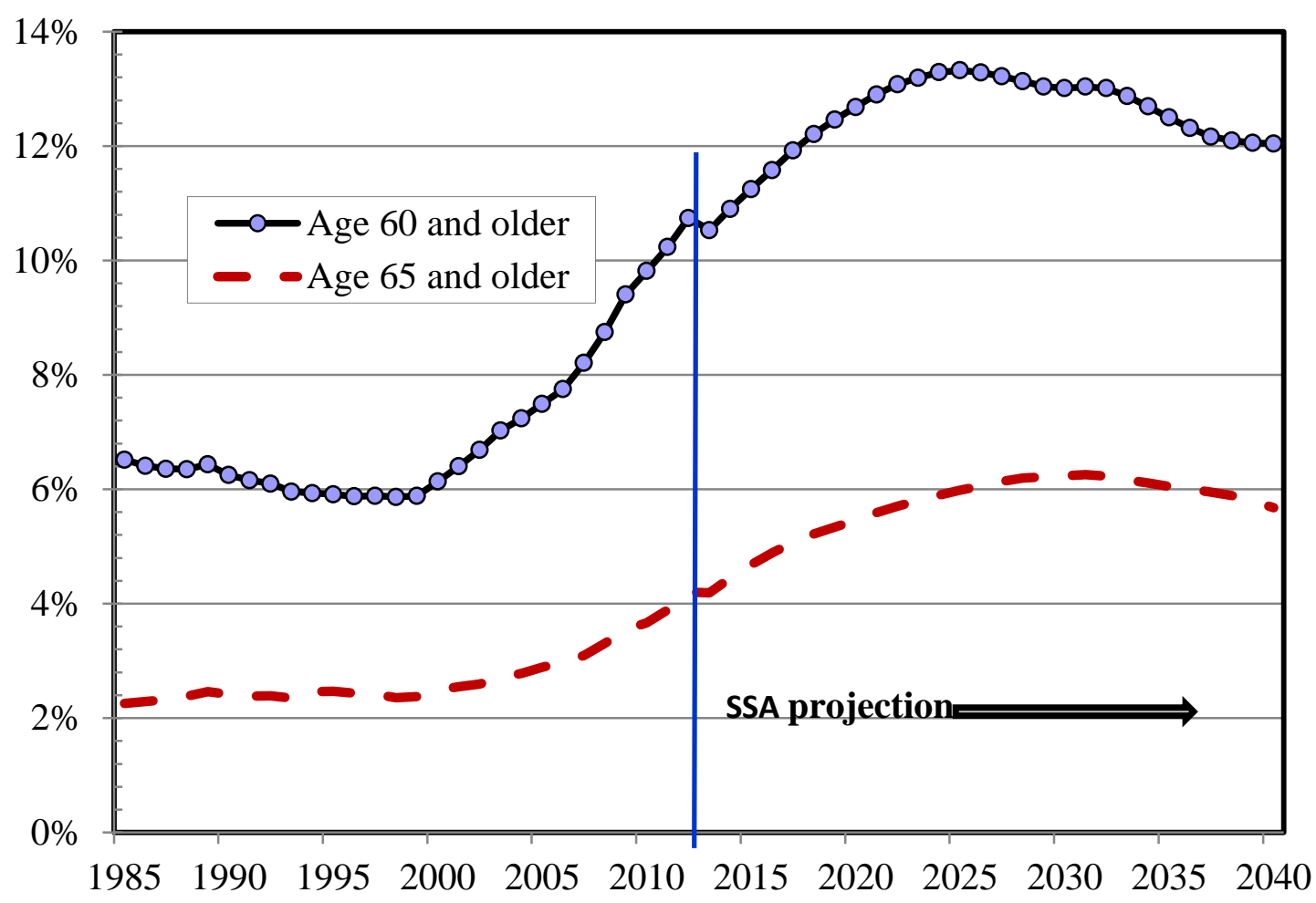

Source: Author's tabulations of U.S. BLS historical data and estimates based on labor force projections of the Social Security Administration for the 2011 OASDI Trustees' report. Tabulations refer to the employed population between ages 16 and 74 . 
Figure 2. Change in Age Structure of the Noninstitutionalized U.S. Population, 1985-2025

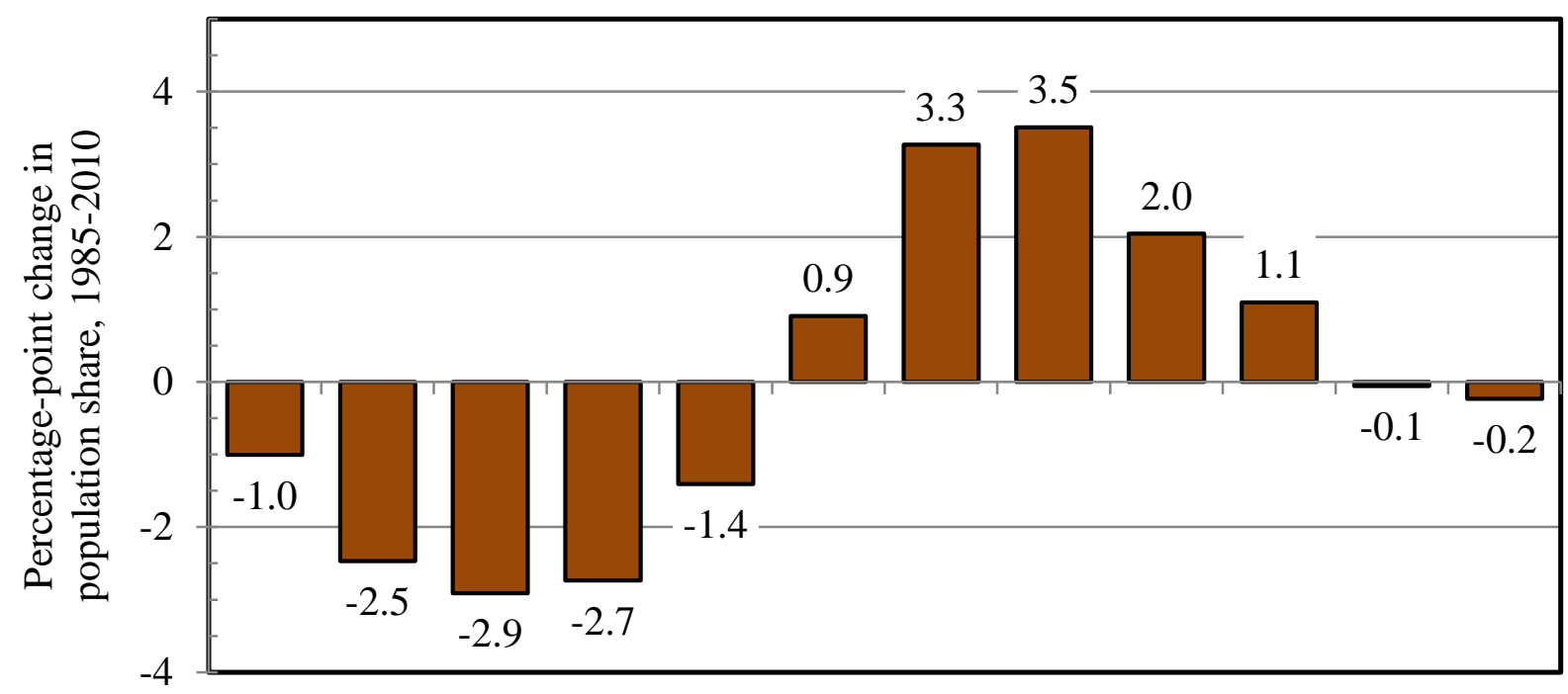

16-19 20-24 25-29 30-34 35-39 40-44 45-49 50-54 55-59 60-64 65-69 70-74

Age group

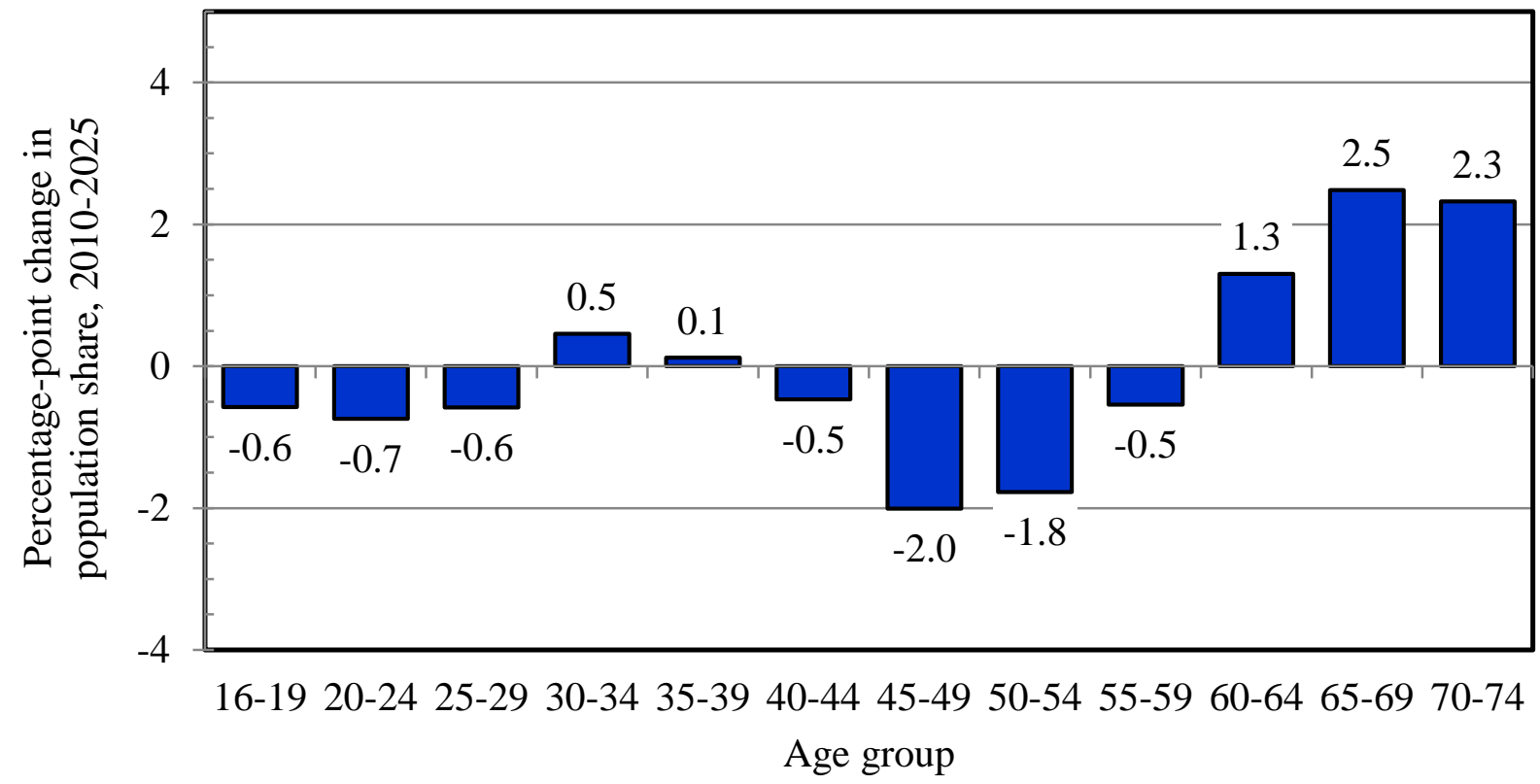

Source: Author's tabulations of U.S. BLS historical data and estimates based on labor force projections of the Social Security Administration for the 2011 OASDI Trustees' report. Tabulations refer to the noninstitutionalized population between ages 16 and 74 . 
Figure 3. Change in Labor Force Participation Rates by Age, 1990-2012
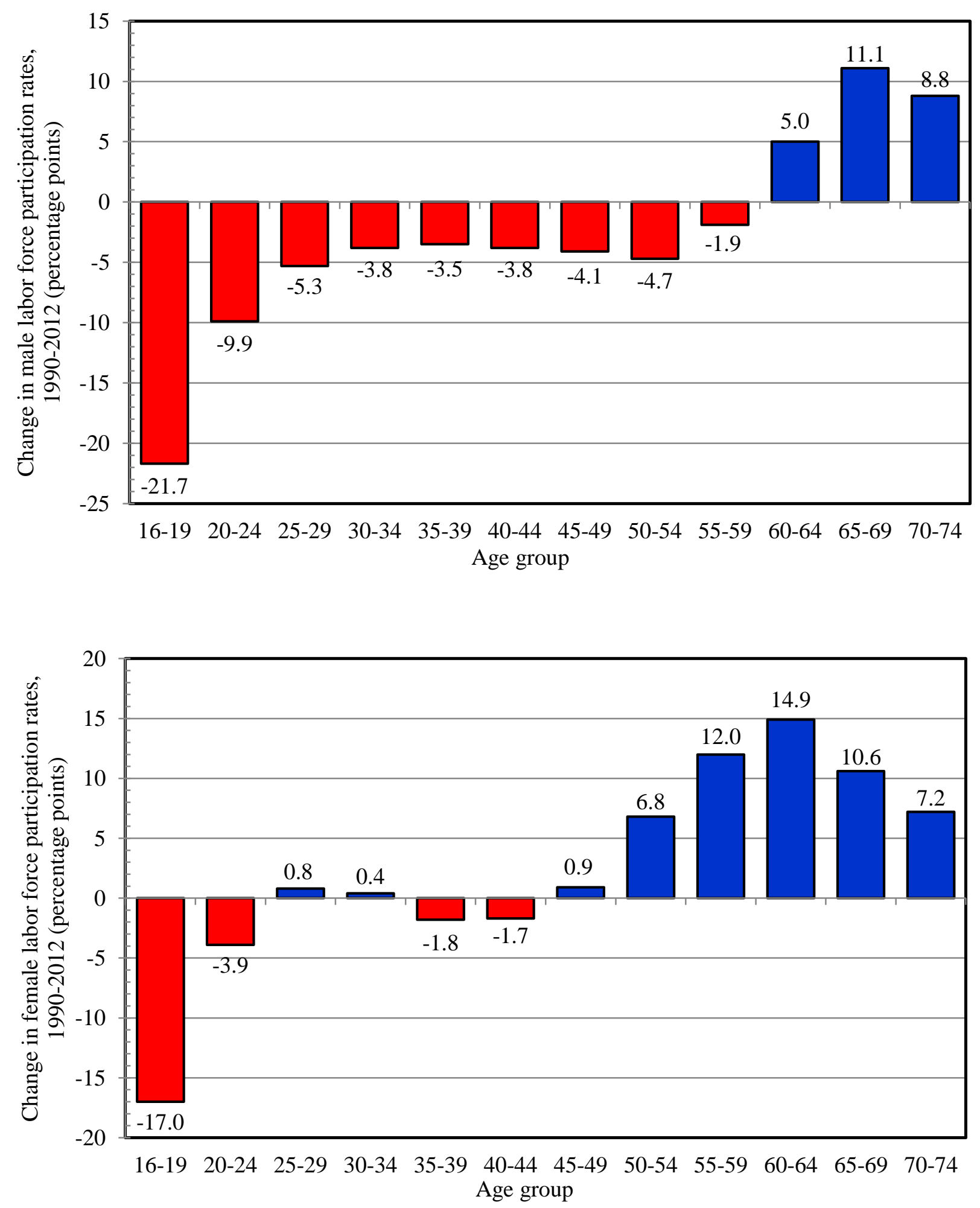

Source: Author's tabulations of U.S. BLS historical data. Tabulations refer to the labor force and population between ages 16 and 74 . 
Figure 4. Percent of Labor Force that is 60 or Older under Alternative Assumptions about Participation Rates, 1985-2030

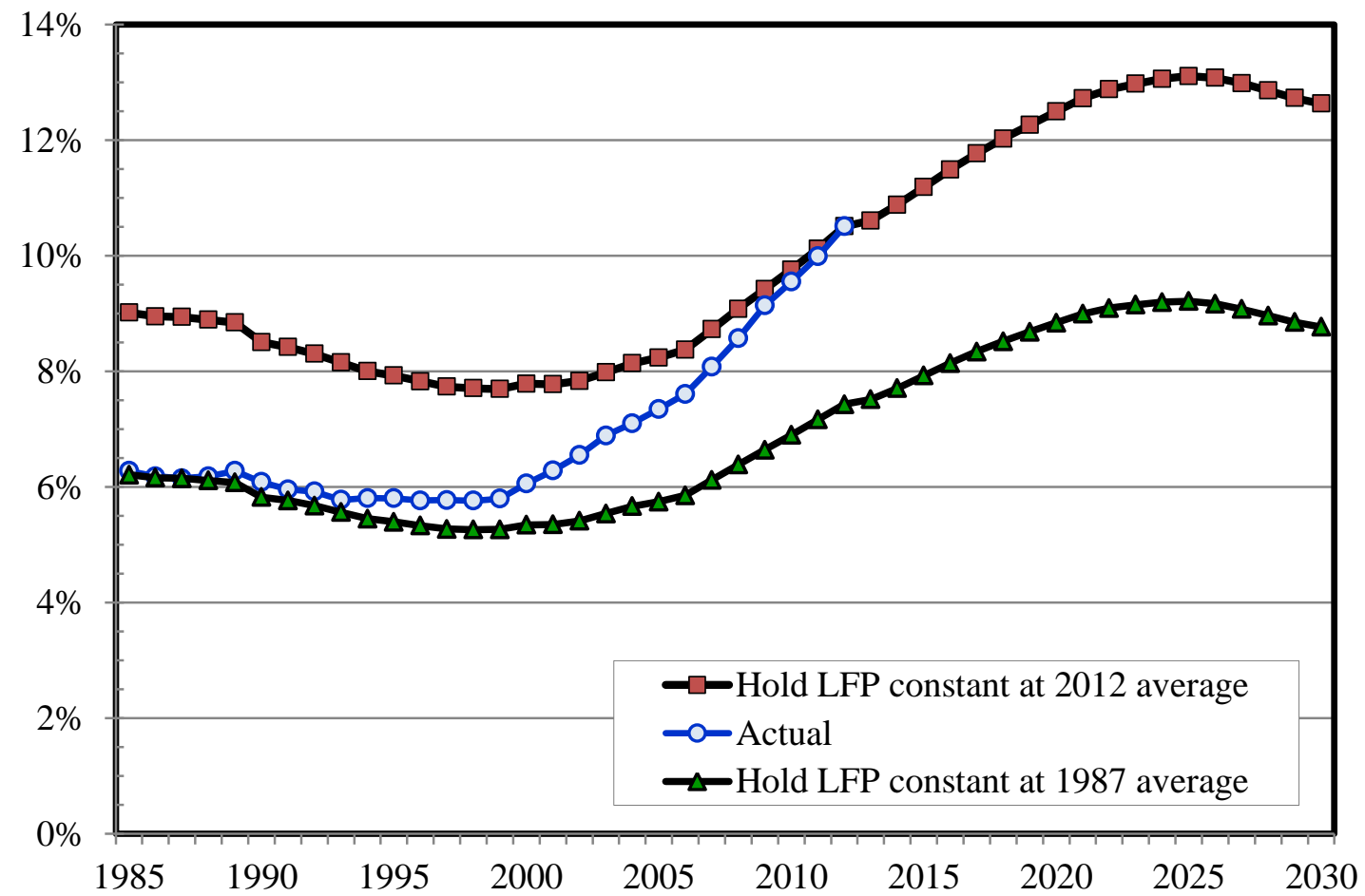

Source: Author's tabulations of U.S. BLS historical data and estimates based on population projections of the Social Security Administration for the 2011 OASDI Trustees' report. Tabulations refer to the U.S. labor force between ages 16 and 74 . 
Figure 5. Proportion of Adults Who Report Earning Labor Income, by Age Group, 1985 and 2010
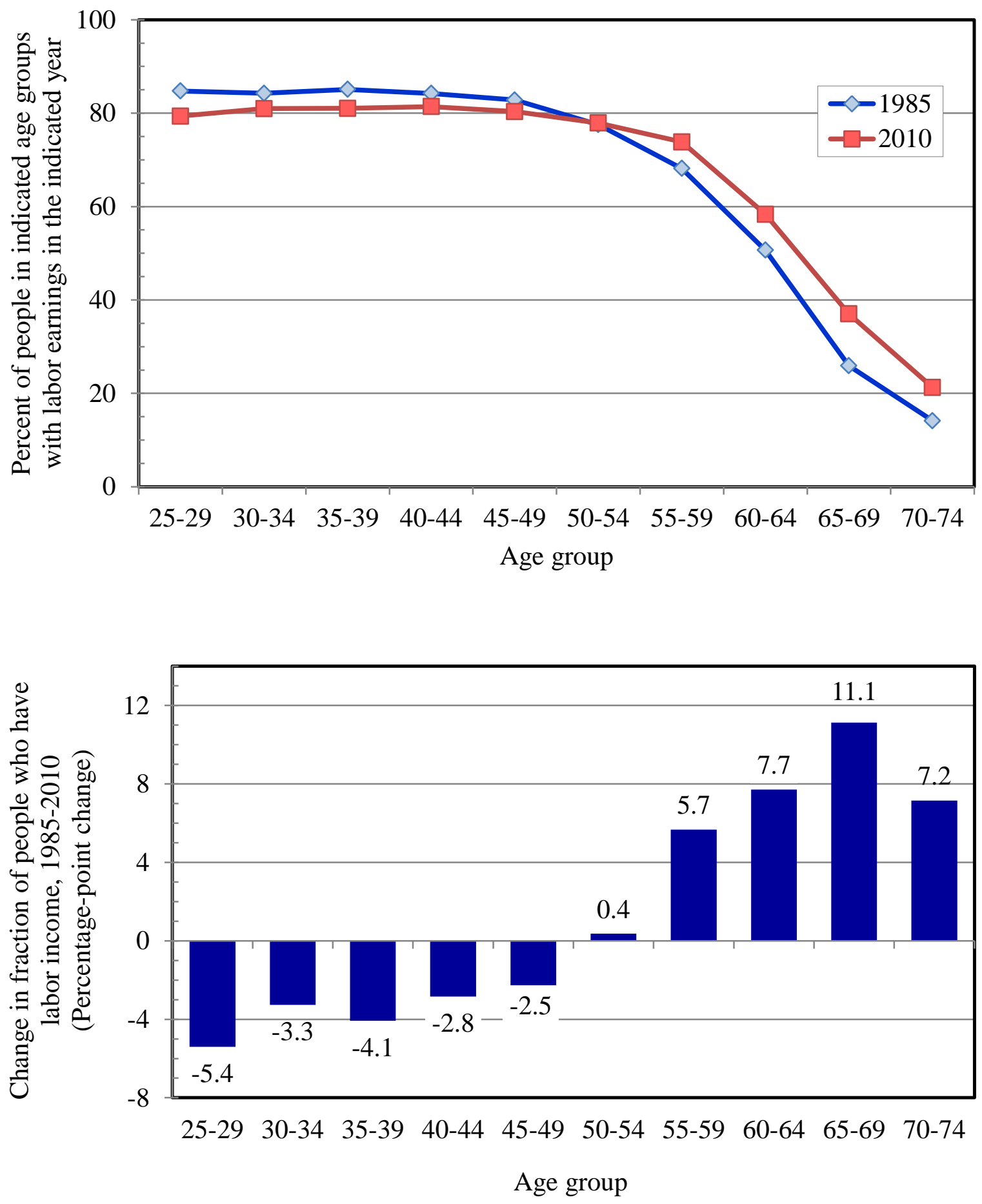

Source: Author's tabulations of March 1986 and March 2011 CPS files. 
Figure 6. Labor Force Participation Rates of Persons 62-74 Years Old by Educational Attainment, 1991-2010

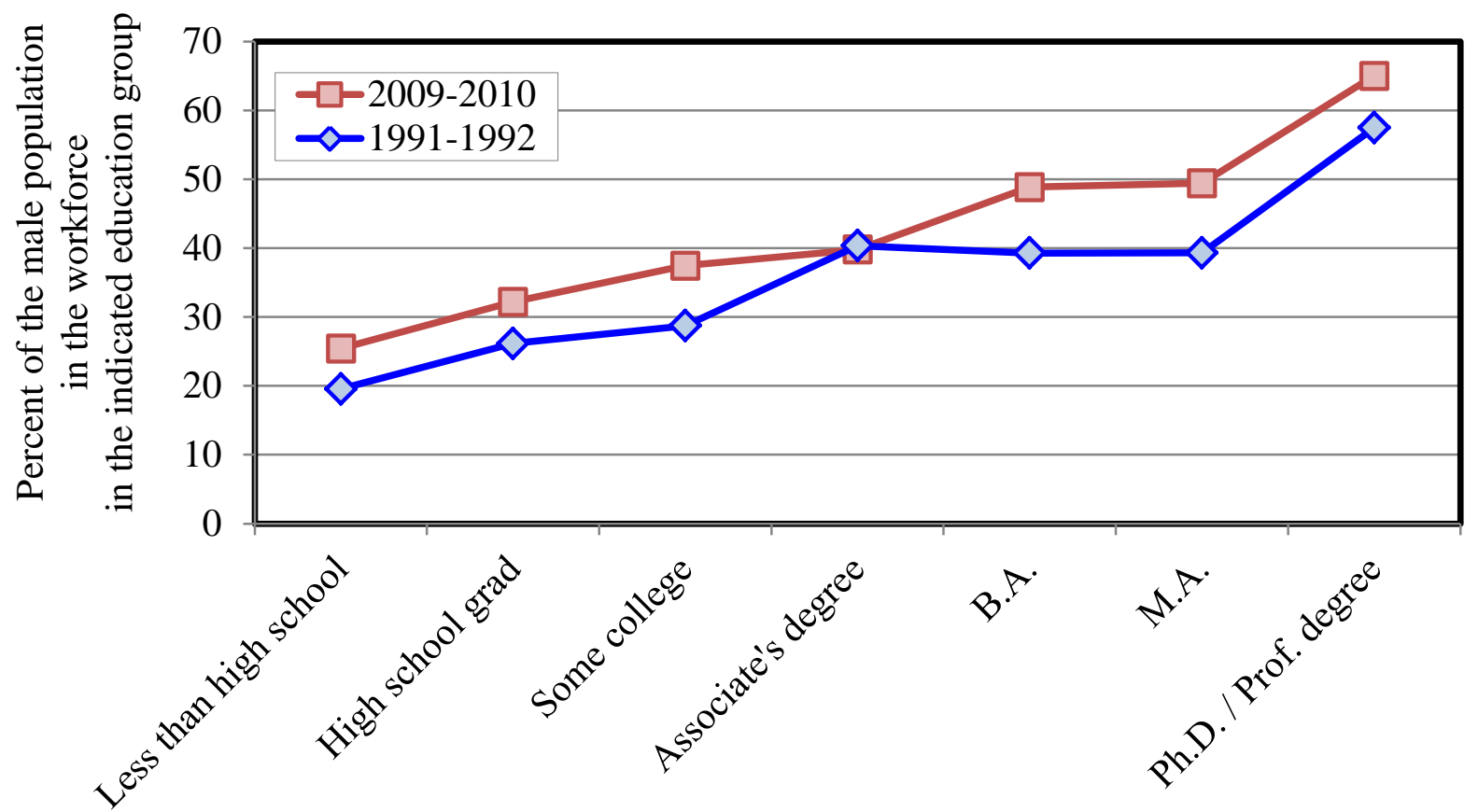

Educational attainment

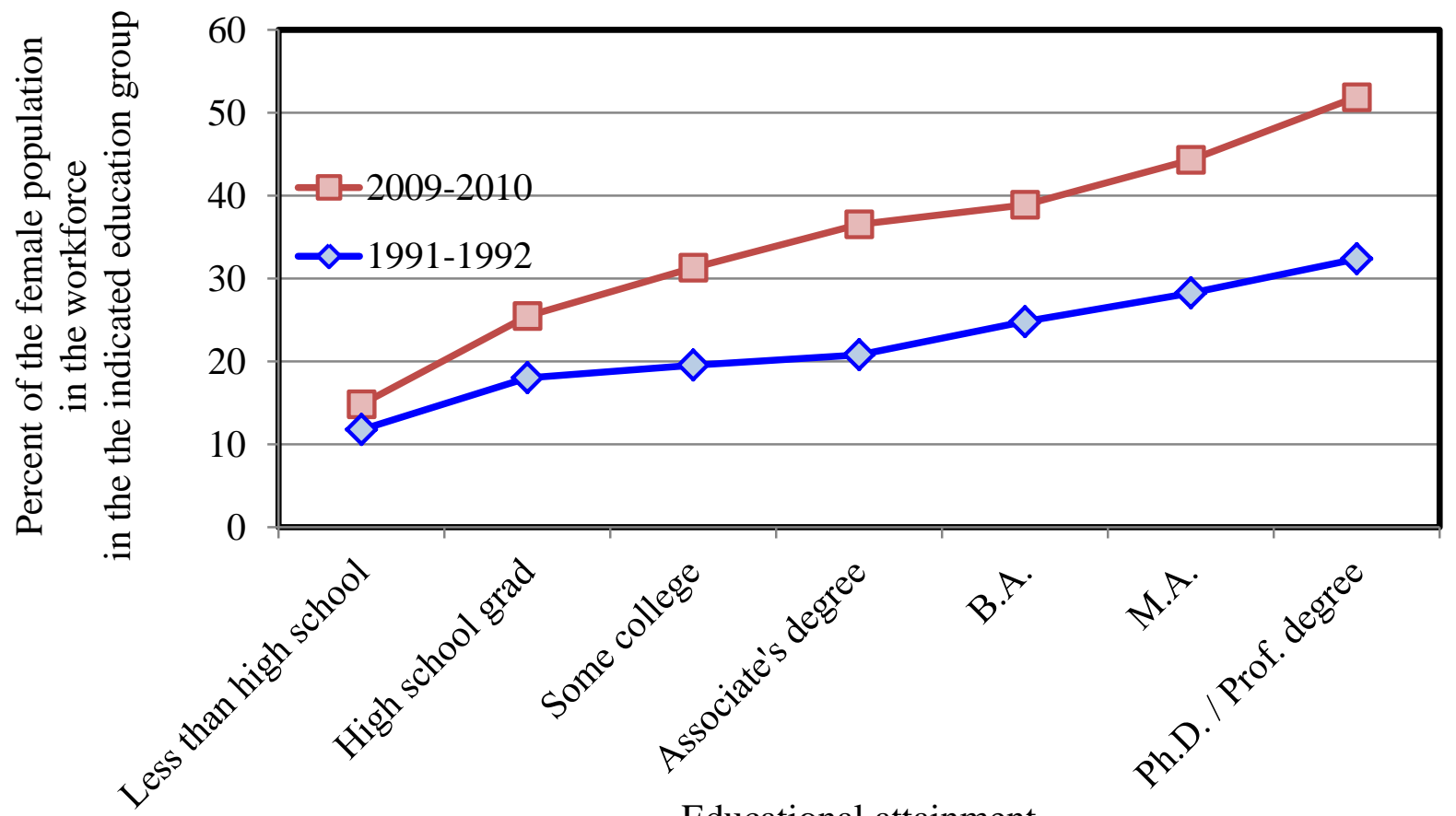

Educational attainment

Source: Author's tabulations of March 1991, 1992, 2009, and 2010 CPS files. 
Figure 7. Trends in Educational Attainment among Americans Age 60-74, 1985-2030
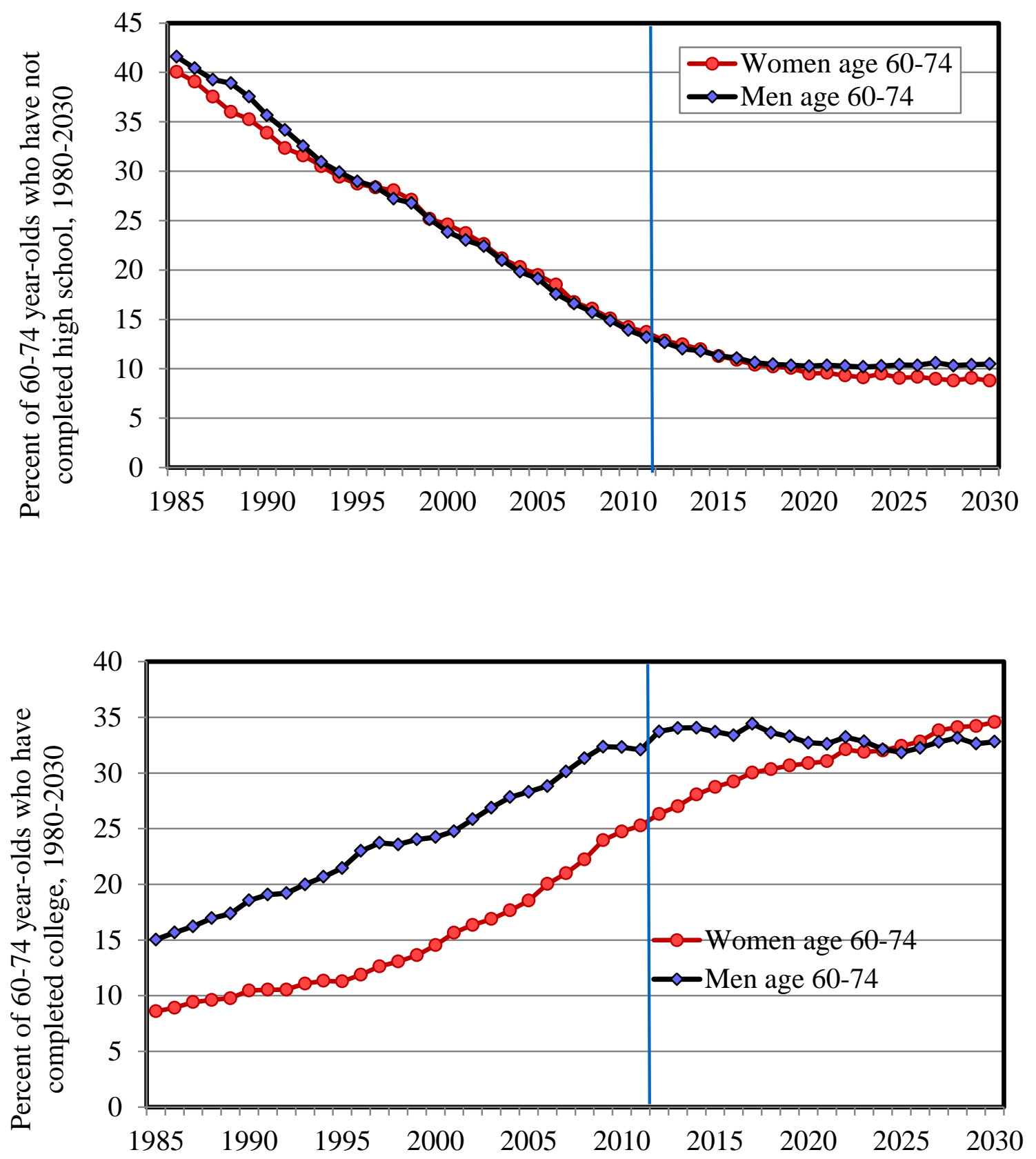

Source: Author's tabulations of 1985-2011 monthly CPS-ORG files and projections of educational attainment as explained in text. 
Figure 8. Percent of Adults without a High School Diploma in Selected Age Groups, 1985-2030
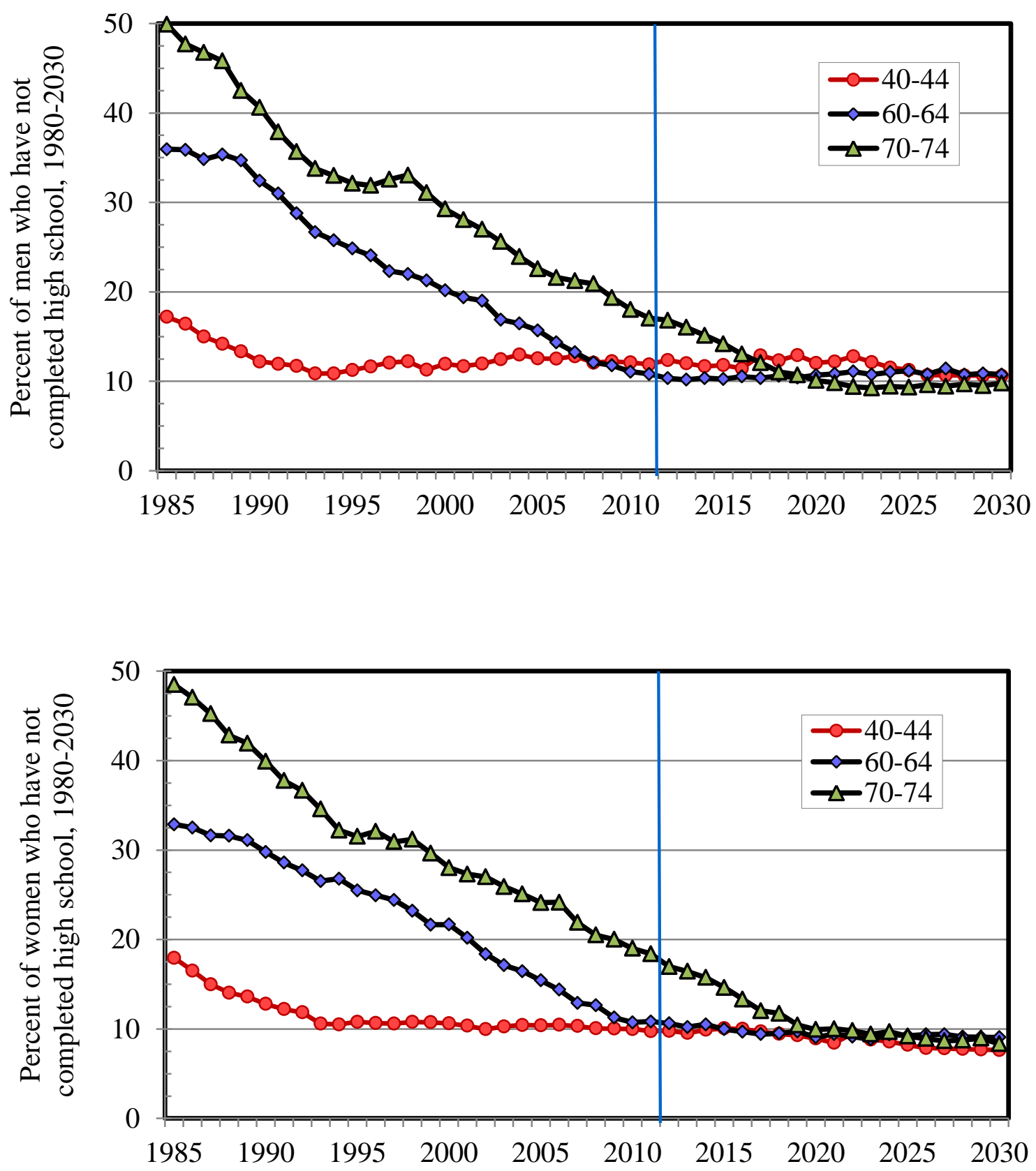

Source: Author's tabulations of 1985-2011 monthly CPS-ORG files and projections of educational attainment as explained in text. 
Figure 9. Percent of Adults Who Have Completed College in Selected Age Groups, 1985-2030
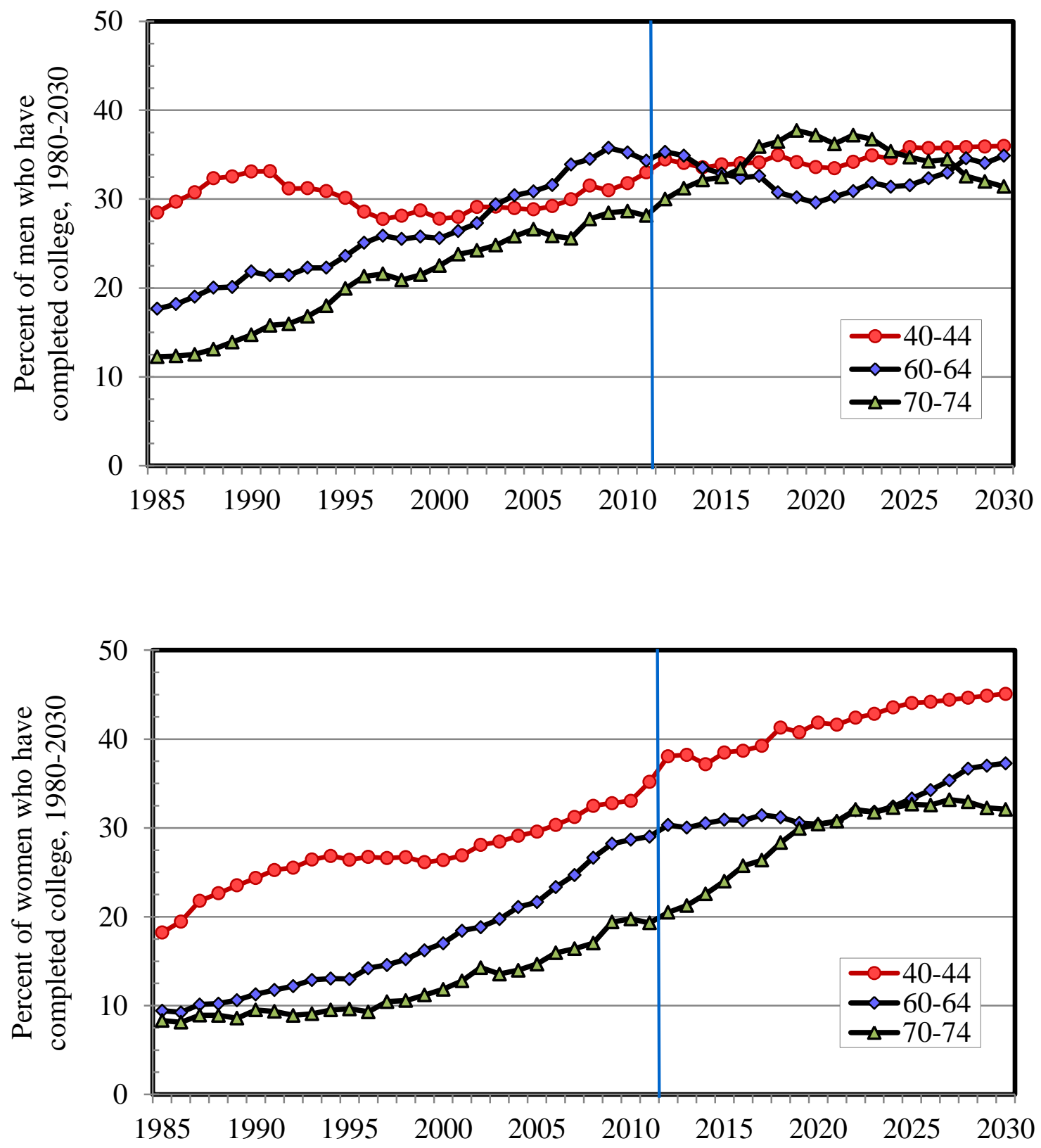

Source: Author's tabulations of 1985-2011 monthly CPS-ORG files and projections of educational attainment as explained in text. 
Figure 10. Age Profile of Annual Earned Income of Adults Who Have Labor Income, 1985 and 2010
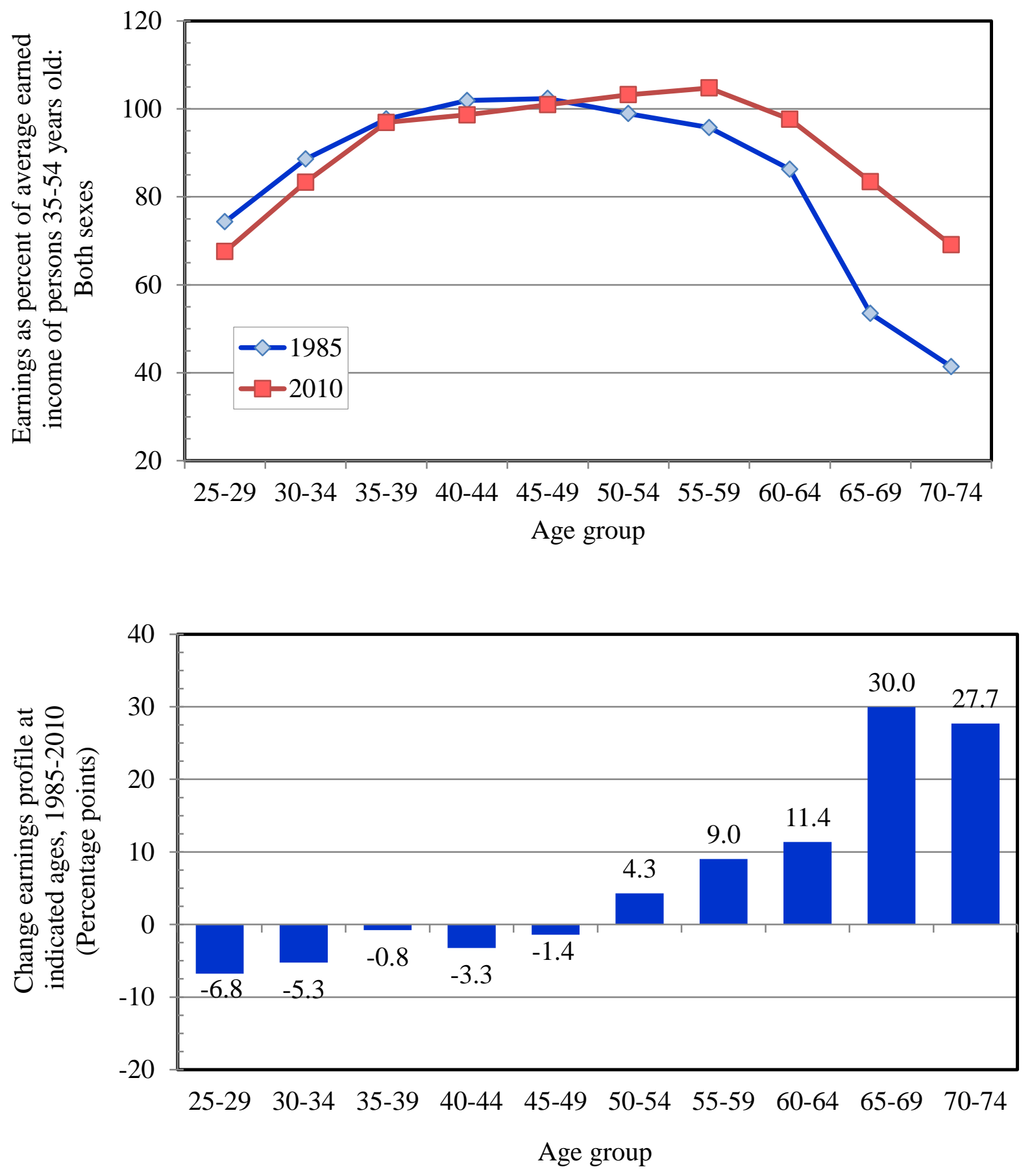

Source: Author's tabulations of March 1986 and March 2011 CPS files. 
Figure 11. Age Profile of Annual Earned Income of Adults, Including Those Who Have No Labor Income, 1985 and 2010

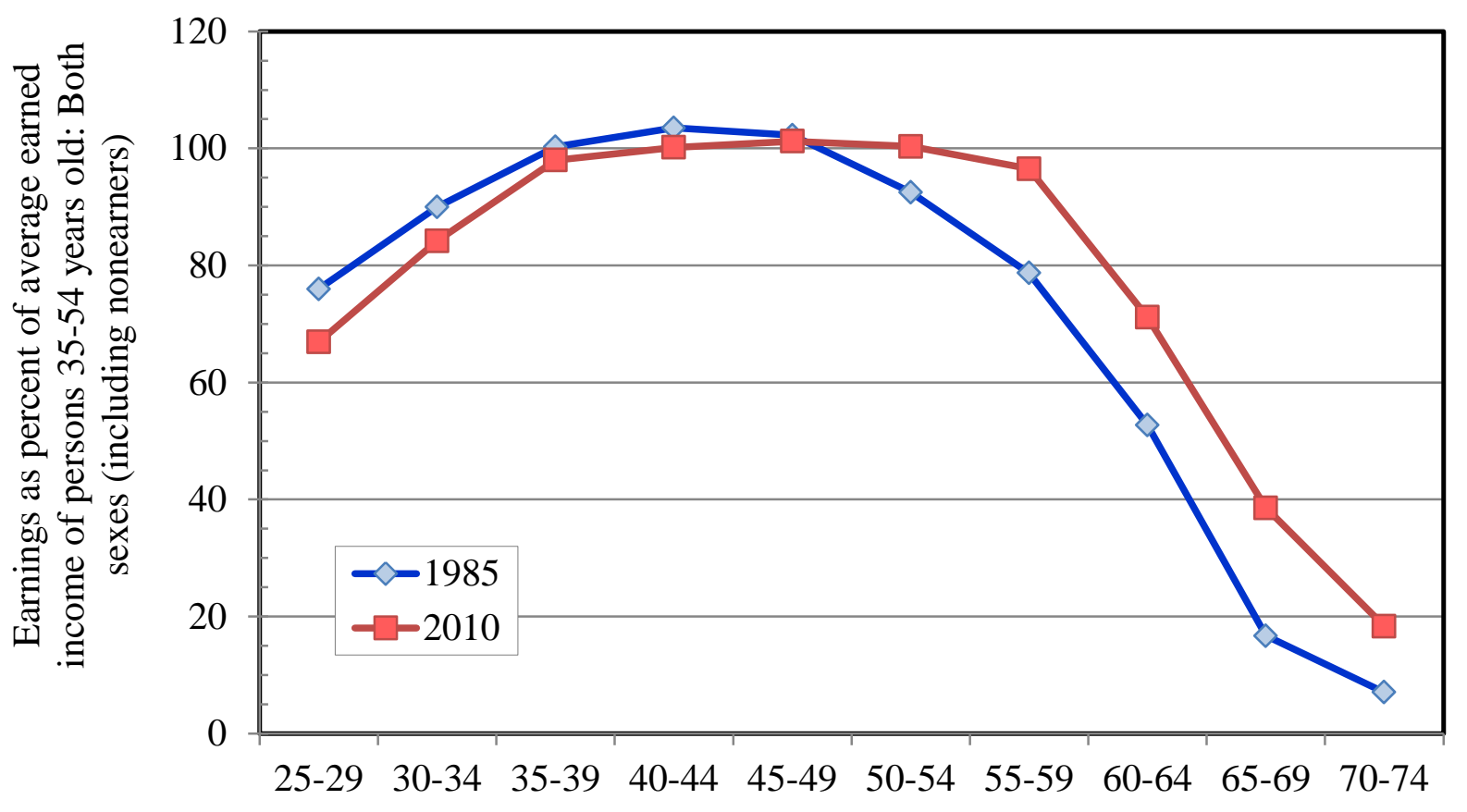

Age group

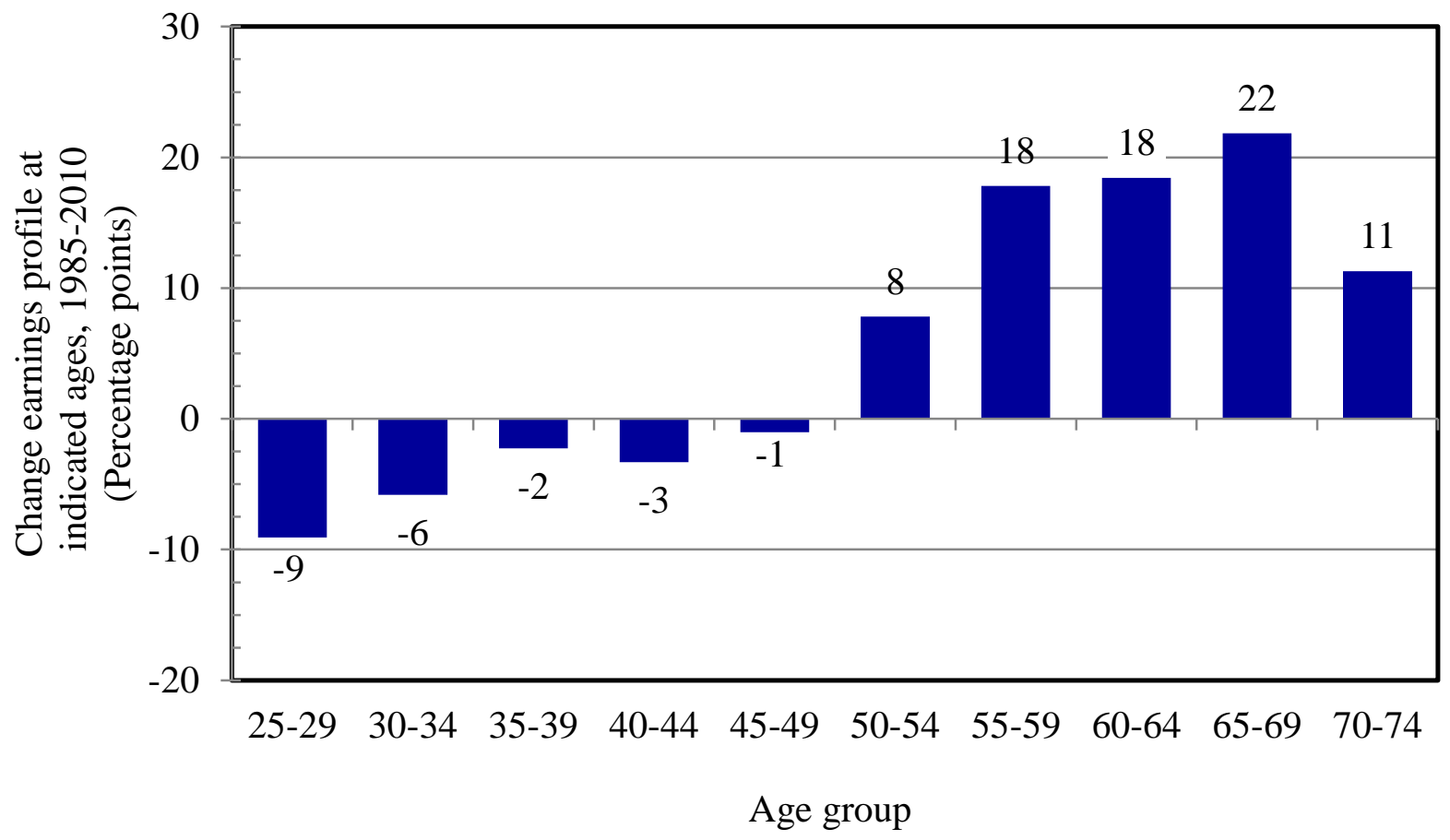

Source: Author's tabulations of March 1986 and March 2011 CPS files. 
Figure 12. Percent of Annual Labor Income Earned by Aged Workers, 1985-2030
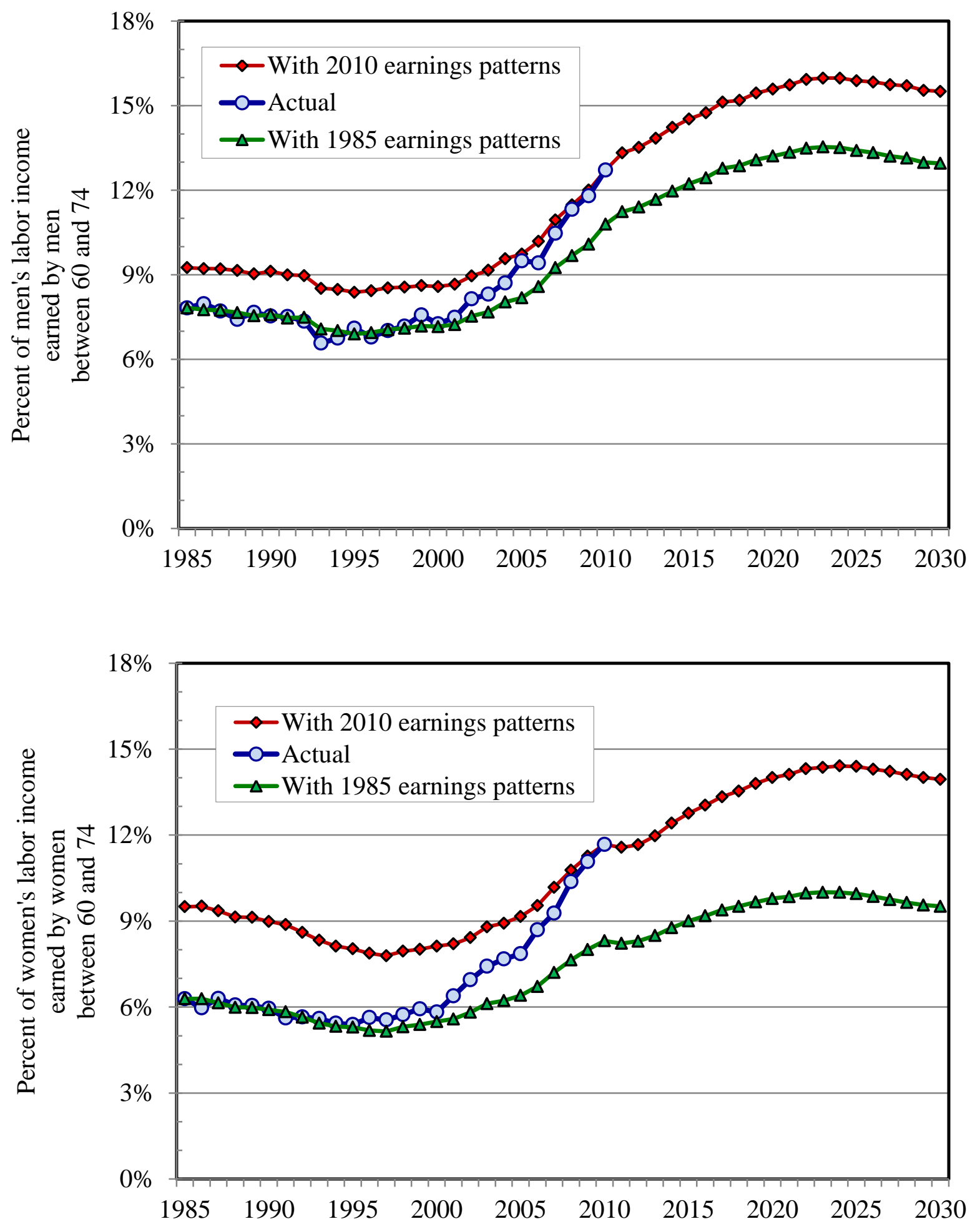

Source: Author's tabulations of 1986-2011 March CPS files and projections of future population as explained in text. Population projections derived from the Social Security Administration for the 2011 OASDI Trustees' report. Tabulations refer to earnings received by workers aged $16-74$. 
Figure 13. Average Wages of Workers Age 60-74 as a Percent of Wages Earned by Workers Age $25-59,1985-2011$
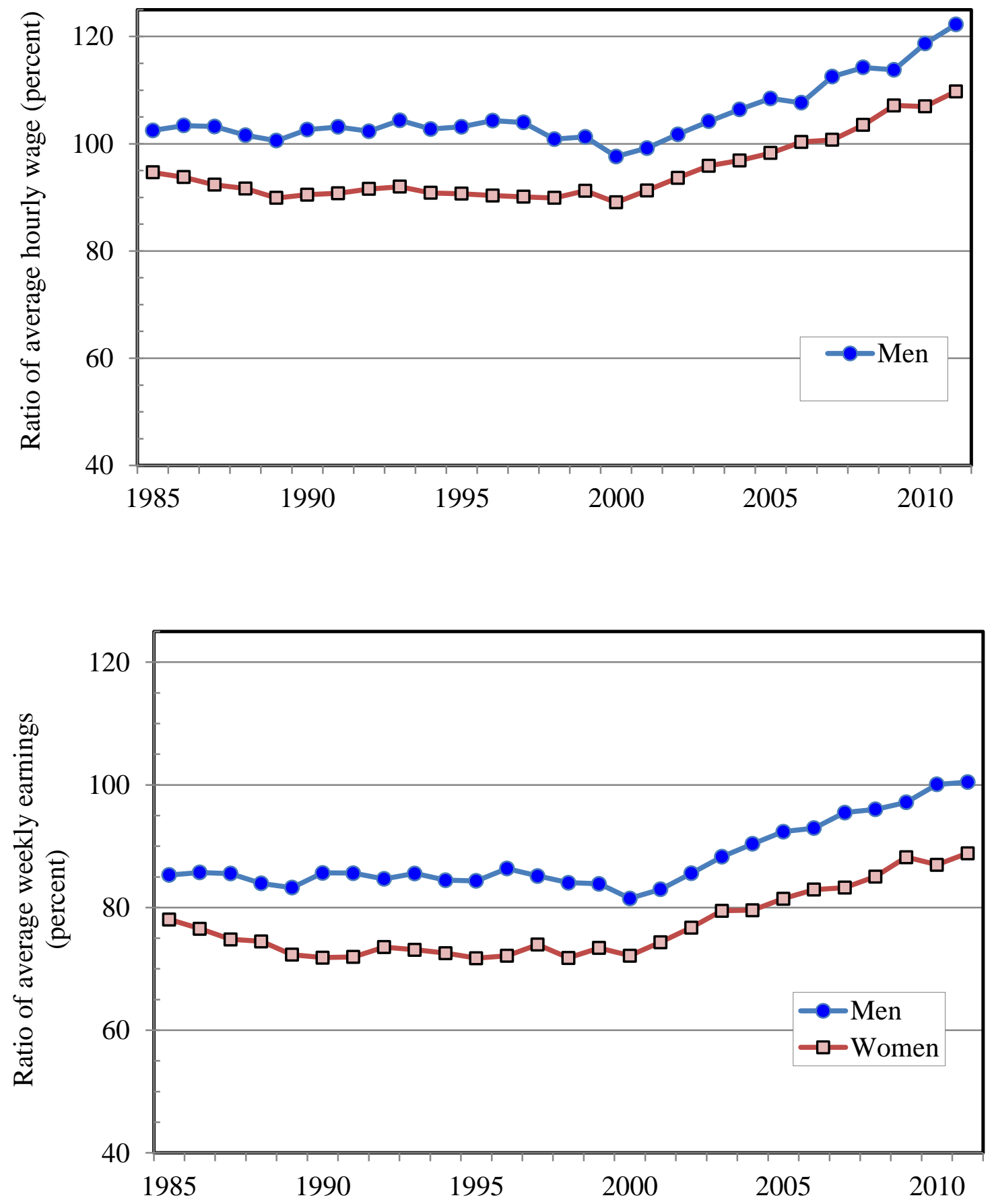

Source: Author's tabulations of 1985-2011 monthly CPS-ORG files. 
Figure 14. Average Annual Earnings of Workers Age 60-74 as a Percent of Earnings of Workers Age 25-59, 1985-2010

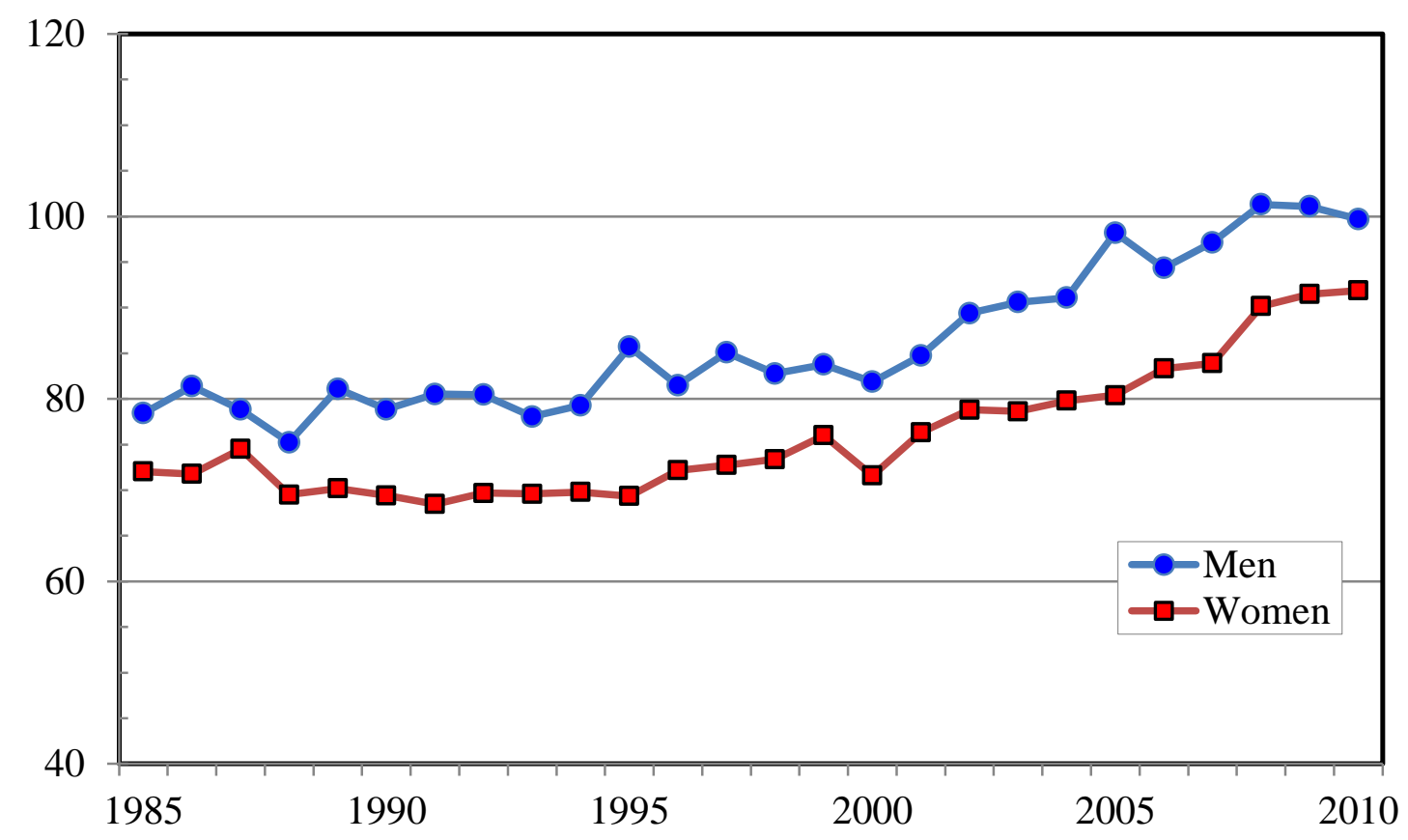

Source: Author's tabulations of 1986-2011 March CPS files. 
Appendix Figure 1. Age-Hourly Wage Profiles of 25-74 Year-old Male Workers by Educational Attainment, 1985-1992 and 2003-2010

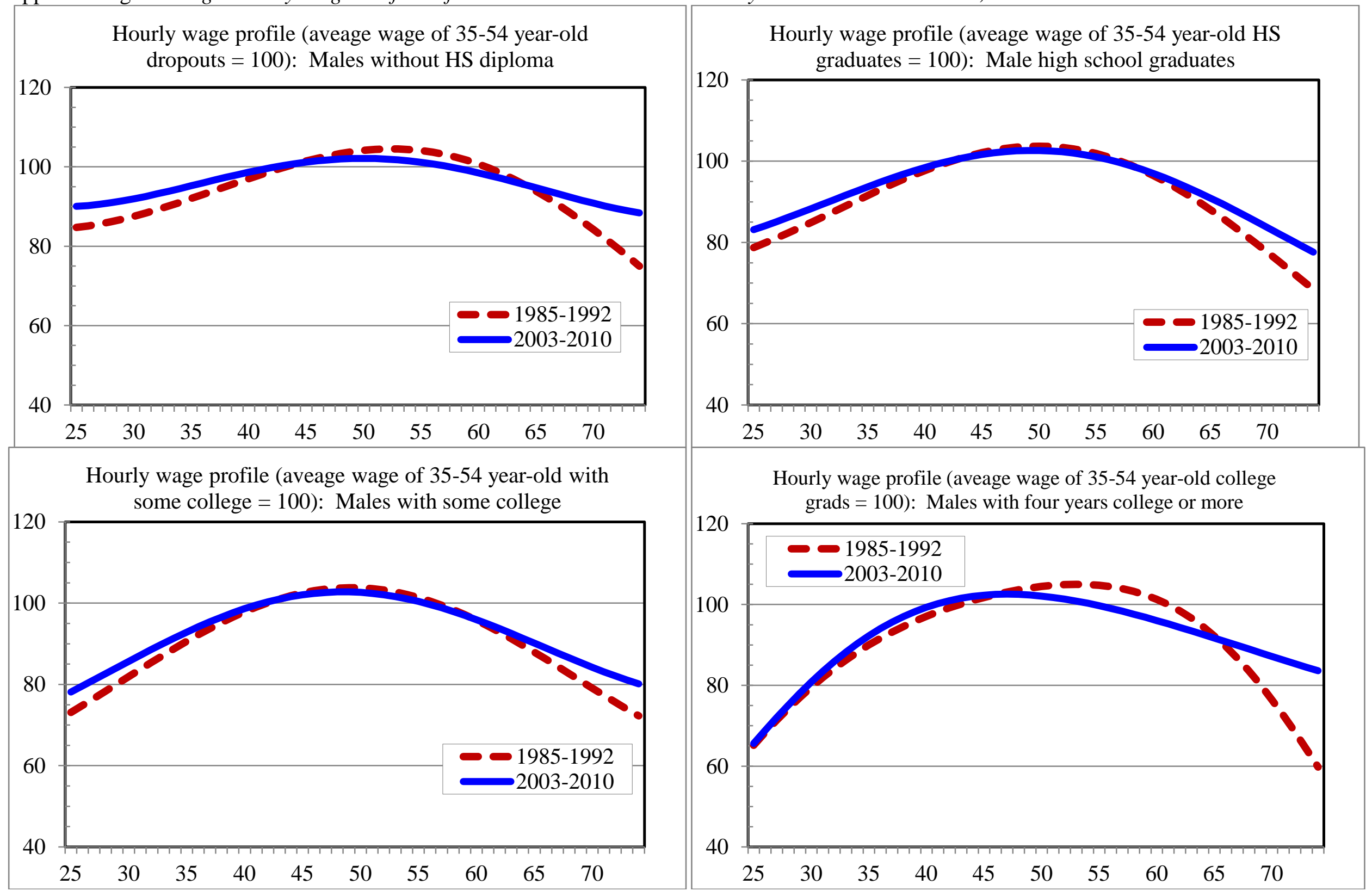

Source: Author's regression analyses of hourly wage data in monthly CPS-ORG public use files for 1985-1992 and 2003-2010 calendar years. 
Appendix Figure 2. Age-Hourly Wage Profiles of 25-74 Year-old Female Workers by Educational Attainment, 1985-1992 and 2003-2010

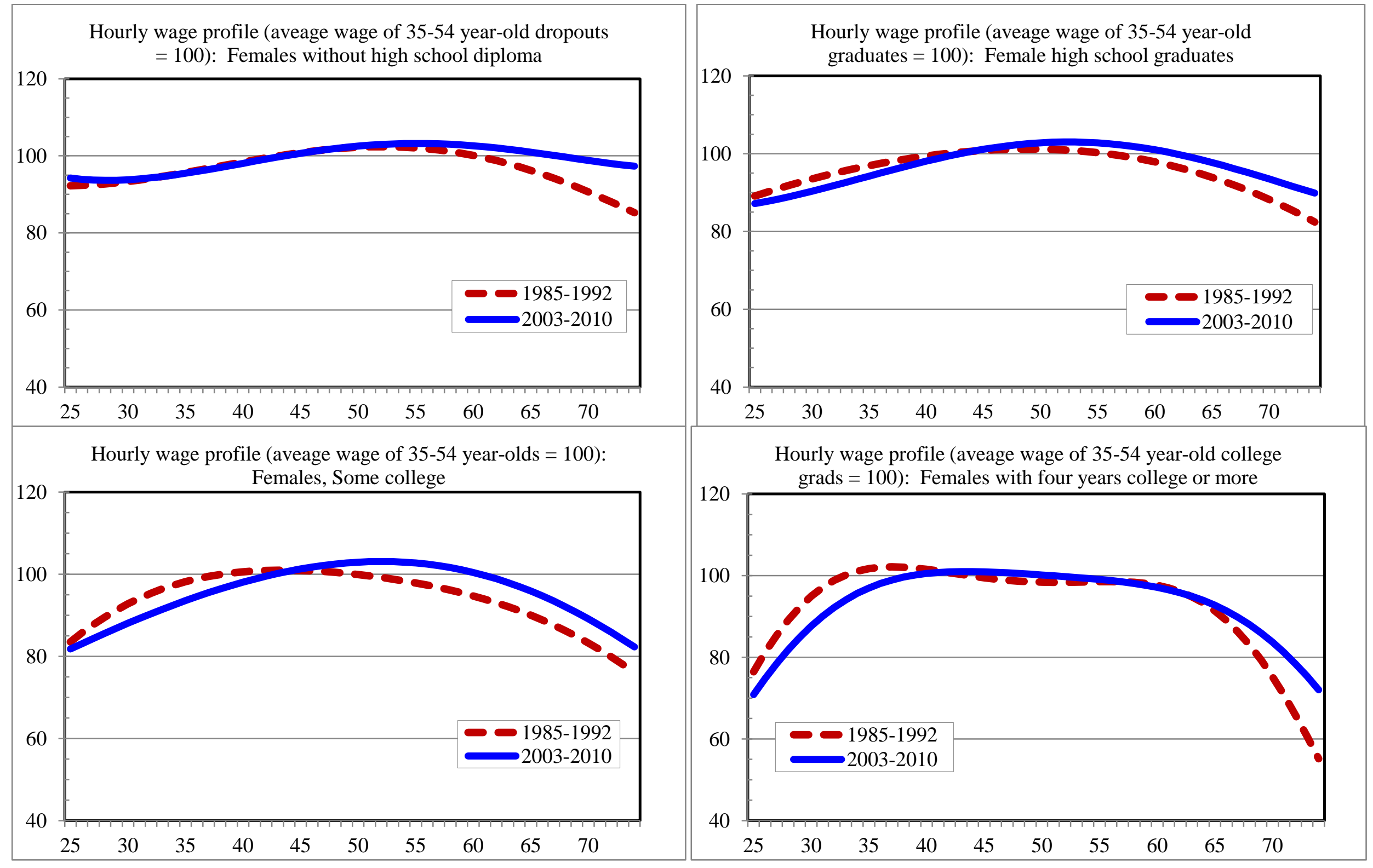

Source: Author's regression analyses of hourly wage data in monthly CPS-ORG public use files for 1985-1992 and 2003-2010 calendar years. 


\section{RECENT WORKING PAPERS FROM THE CENTER FOR RETIREMENT RESEARCH AT BOSTON COLLEGE}

Does Access to Health Insurance Influence Work Effort Among Disability Cash Benefit Recipients?

Norma B. Coe and Kalman Rupp, April 2013

How Will Older Workers Who Lose Their Jobs During the Great Recession Fare in the Long-Run?

Matthew S. Rutledge, Natalia Orlova, and Anthony Webb, March 2013

Can Long-Term Care Insurance Partnership Programs Increase Coverage and Reduce Medicaid Costs?

Wei Sun and Anthony Webb, March 2013

SSI for Disabled Immigrants: Why Do Ethnic Networks Matter?

Delia Furtado and Nikolaos Theodoropoulos, February 2013

The Use of VA Disability Benefits and Social Security Disability Insurance Among Veterans

Janet M. Wilmoth, Andrew S. London, and Colleen M. Heflin, February 2013

How Does the Composition of Disability Insurance Applicants Change Across Business Cycles?

Norma B. Coe and Matthew S. Rutledge, February 2013

The Economic Implications of the Department of Labor's 2010 Proposals for BrokerDealers

Alicia H. Munnell, Anthony Webb, and Francis M. Vitagliano, January 2013

What Is the Long-Term Impact of Zebley on Adult and Child Outcomes?

Norma B. Coe and Matthew S. Rutledge, January 2013

Sticky Ages: Why Is Age 65 Still a Retirement Peak?

Norma B. Coe, Mashfiqur R. Khan, and Matthew S. Rutledge, January 2013

Rethinking Optimal Wealth Accumulation and Decumulation Strategies in the Wake of the Financial Crisis

Richard W. Kopcke, Anthony Webb, and Josh Hurwitz, January 2013

Employee Mobility and Employer-Provided Retirement Plans

Gopi Shah Goda, Damon Jones, and Colleen Flaherty Manchester, November 2012

All working papers are available on the Center for Retirement Research website

(http://crr.bc.edu) and can be requested bye-mail (crr@bc.edu) or phone (617-552-1762). 